\title{
Simulated Greenland Surface Mass Balance in the GISS ModelE2 GCM: Role of the Ice Sheet Surface
}

P. M. Alexander ${ }^{1,2}$, A. N. LeGrande ${ }^{2}$, E. Fischer ${ }^{3}$, M. Tedesco ${ }^{1,2}$, X. Fettweis ${ }^{4}$, M. Kelley $^{2,5}$, S. M. J. Nowicki' ${ }^{6}$ and G. A. Schmidt ${ }^{2}$

${ }^{1}$ Lamont Doherty Earth Observatory, Columbia University, Palisades, NY, USA.

${ }^{2}$ NASA Goddard Institute for Space Studies, New York, NY, USA.

${ }^{3}$ Center For Climate Systems Research, Columbia University, New York, NY, USA.

${ }^{4}$ Laboratory of Climatology, Department of Geography, University of Liège, Liège, Belgium.

${ }^{5}$ SciSpace, LLC, New York, NY, USA.

${ }^{6}$ NASA Goddard Space Flight Center, Greenbelt, MD, USA.

Corresponding author: Patrick Alexander (pma2107@1deo.columbia.edu)

\section{Key Points:}

- The ModelE2 GCM captures average Greenland surface mass balance (SMB) from a regional model, but there are differences in SMB components.

- Representation of surface albedo, roughness length, and refreezing substantially influence GCM-simulated Greenland surface mass balance.

- An elevation class scheme locally improves SMB. Ice sheet-wide SMB changes are small, but other factors could magnify these effects.
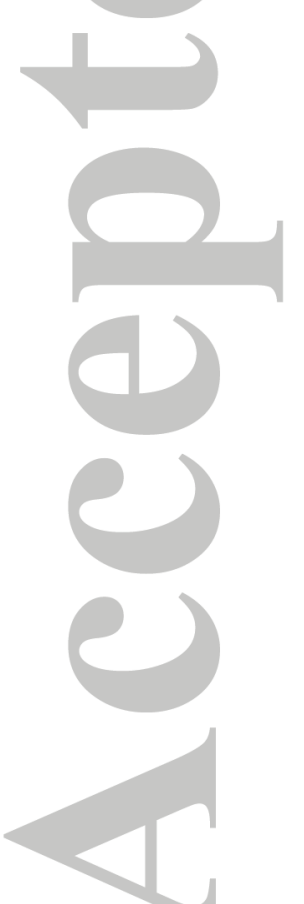

This article has been accepted for publication and undergone full peer review but has not been through the copyediting, typesetting, pagination and proofreading process which may lead to differences between this version and the Version of Record. Please cite this article as doi: $10.1029 / 2018 J F 004772$ 


\section{Abstract}

The rate of growth or retreat of the Greenland and Antarctic ice sheets remains a highly uncertain component of future sea level change. Here we examine the simulation of Greenland ice sheet surface mass balance (GrIS SMB) in the NASA Goddard Institute for Space Studies (GISS) ModelE2 General Circulation Model (GCM). GCMs are often limited in their ability to represent SMB compared with polar-region Regional Climate Models (RCMs). We compare ModelE2 simulated GrIS SMB for present-day (1996-2005) simulations with fixed ocean conditions, at a spatial resolution of $2^{\circ}$ latitude by $2.5^{\circ}$ longitude $(-200 \mathrm{~km})$, with SMB simulated by the Modèle Atmosphérique Régionale (MAR) RCM (1996-2005 at a $25 \mathrm{~km}$ resolution). ModelE2 SMB agrees well with MAR SMB on the whole, but there are distinct spatial patterns of differences and large differences in some SMB components. The impact of changes to the ModelE2 surface are tested, including a sub-grid-scale representation of SMB with surface elevation classes. This has a minimal effect on ice sheet-wide SMB, but corrects local biases. Replacing fixed surface albedo with satellite-derived values and an age-dependent scheme has a larger impact, increasing simulated melt by $60-100 \%$. We also find that lower surface albedo can enhance the effects of elevation classes. Reducing ModelE2 surface roughness length to values closer to MAR reduces sublimation by $\sim 50 \%$. Further work is required to account for meltwater refreezing in ModelE2, and to understand how differences in atmospheric processes and model resolution influence simulated SMB.

\section{Plain Language Summary}

Melting of the Earth's ice sheets represents a substantial contribution to global sea level rise. Global climate model simulations of earth's climate often model the surface of ice sheets in a fairly simple way because of computational limitations. This study evaluates the representation of the Greenland ice sheet in one such global model simulation (NASA's ModelE2) against a regional model that simulates only the local Greenland area in a higher degree of detail. The study finds that the global model simulation of the Greenland ice sheet is sensitive to how the model represents the ice sheet surface, in particular, how it reflects incoming sunlight, stores and freezes liquid water, and simulates surface evaporation. Attempting to improve the simulation by dividing the ice sheet surface into additional grid cells according to surface elevation has a minor impact on the simulation. The study reveals how the representation of the Greenland ice sheet in ModelE2 might be improved to better estimate ice sheet change and the sea level response to global climate changes. 


\section{Introduction}

In recent decades, ice sheets, in particular the Greenland ice sheet (GrIS) have been losing mass as shown by both satellite-derived and model estimates (Khan et al., 2015; Shepherd et al., 2012; Velicogna et al., 2017). These mass changes have been linked to both changes in surface mass balance (SMB; the balance between accumulation, runoff, net sublimation and evaporation on the ice sheet surface, e.g. van den Broeke et al., 2016) and changes in ice dynamics; the accelerated flow of ice sheets into the sea (e.g. Enderlin et al., 2014; Rignot et al., 2011). For the GrIS, changes in SMB are estimated to have contributed to roughly $60 \%$ of GrIS mass loss for the period 1991-2015 (van den Broeke et al., 2016).

The best means of currently estimating spatially and temporally continuous fields of ice sheet SMB is through the use of regional climate model (RCM) simulations, forced at the lateral boundaries with reanalysis or GCM outputs as direct observations of these quantities at these scales are not currently possible (e.g. Fettweis et al., 2017; Langen et al., 2017; Lenaerts et al., 2012; Noël et al., 2015). However, only general circulation models (GCMs), have the capability of fully capturing feedbacks between the ice sheets, atmosphere and oceans in future and historical simulations. GCMs also do not suffer from errors in energy and mass budget closure that occur in RCMs, but their representation of ice sheet processes is generally simpler, and they do not have the high spatial resolution needed to resolve the narrow ablation areas present on ice sheets (Church et al., 2013; Cullather et al., 2014). Future projections of ice sheet mass balance have therefore typically combined GCM outputs with simple energy balance models or positive degree-day models (e.g. Reeh, 1991) and ice sheet models (ISMs) to project future ice sheet mass change (e.g. Bindschadler et al., 2013; Nowicki et al., 2013). More recent work has involved improving schemes within GCMs (Vizcaino et al., 2013; Lenaerts et al., 2013; Helsen et al., 2017). The most recent iteration of the Ice Sheet Model Intercomparison Project- Phase 6 (ISMIP6) will include a set of experiments involving coupling between GCMs and ISMs (Nowicki et al., 2016).

In view of the need for improved GCM simulations of ice sheet mass balance, we conduct a first evaluation of SMB simulated by the NASA GISS ModelE2 GCM (Schmidt et al., 2014), for which a scheme for ISM-GCM coupling is under development (e.g. Fischer et al., 2014). To provide an indication of how ModelE2-simulated SMB and components compare with RCM simulations, we compare ModelE2 against outputs of an RCM forced with reanalysis data over the same 1996-2005 period. With the ultimate goal of improving model simulations of GCM SMB, we evaluate the impact of variations on the current 
ModelE2 simulation of the land ice surface on simulation of SMB components. Adjustments to model schemes are motivated by large differences in GCM vs. RCM melt, runoff, and sublimation. One adjustment includes a scheme for sub-grid-scale surface elevation classes (Fischer et al., 2014), which mitigates the inability of the coarse resolution GCM to capture regions of high gradients in temperature and SMB along the GrIS margins. Similar schemes were employed in other studies (e.g. Vizcaino et al., 2013) but to our knowledge the relative importance of elevation classes to SMB at the GCM resolution has not been separately evaluated. We also test the impact of changes in surface albedo, which has been found to be particularly important for simulation GrIS SMB (e.g. Helsen et al., 2017; Cullather et al., 2014). Finally, we examine the impact of changes to simulated surface roughness length on simulated evaporation and sublimation, as these quantities are high in ModelE2 relative to other models (Cullather et al., 2014). As we focus on the surface, we do not perform detailed tests of the impact of other changes such as the effects of spatial resolution and various atmospheric parameters, but these are also important factors to consider in climate model simulations of SMB (e.g. Cullather et al., 2014; Ettema et al., 2009).

\section{Models, Data and Methods}

\subsection{NASA GISS ModelE2 GCM}

The NASA Goddard Institute for Space Studies earth system model ModelE2 (Hansen et al., 1983; Schmidt et al., 2014, 2006) simulates components of the atmosphereland-ocean-ice system and the feedbacks between them, and has been found to agree well with global observations of radiative fluxes, temperatures, and atmospheric water vapor with some differences in cloud cover and latent and sensible heat fluxes (Schmidt et al., 2014). The atmospheric physics parameterizations employed in this study include most of the updates differentiating ModelE2.1, which will be used in Phase 6 of the Coupled Model Intercomparison Project (CMIP6; Eyring et al., 2016), from ModelE2 (Schmidt et al 2014). For the overall climate, the most impactful of these are a new boundary-layer treatment (Yao and Cheng, 2012), modifications to the moist convection scheme (Kim et al., 2012), the formulation of mixed-phase stratiform cloud processes, and re-generated lookup tables for longwave radiation from Rothman et al. (2013). The model version used here has not been tuned to ensure global radiative balance, which will likely result in some differences in cloud features and radiative fluxes relative to ModelE2.1.

Simulations are performed with a spatial resolution of $2^{\circ}$ latitude by $2.5^{\circ}$ longitude 
(with grid cell dimensions of $\sim 30$ to $\sim 140 \mathrm{~km}$ zonally by $220 \mathrm{~km}$ meridionally over the GrIS), with 40 atmospheric layers at fixed pressure levels up to $0.1 \mathrm{mb}$ (Schmidt et al., 2014). We perform a simulation with climatological ocean surface temperatures, sea ice concentration, and atmospheric composition for the period 1996-2005, and free-running atmospheric variability. In Section 3.1, we provide a brief comparison with a simulation for which u and $\mathrm{v}$ winds were nudged (with a nudging coefficient of 0.001) to align with winds from the NASA Modern-Era Retrospective Analysis for Research and Applications, Version 2 (MERRA-2; Gelaro et al., 2017) for the 1996-2005 period.

We run 11-year simulations with various configurations of ice sheet parameters (see Section 2.4), excluding results from the first year of simulation to allow for model equilibration. To avoid inter-model differences in ice mask, the grid cell ice sheet topography and ice fraction are obtained by re-gridding MAR topography and ice mask (at a $25 \mathrm{~km}$ resolution, derived from Bamber et al., 2013) the ModelE2 grid using the conservative regridding scheme of Fischer et al. (2014). In MAR each pixel is assigned a percentage ice cover. We define a binary ice sheet mask from MAR based on the criterion that a MAR ice sheet pixel has greater than 50\% ice cover (following Fettweis et al., 2011). The binary ice sheet mask on the MAR grid is then used to define percentage ice cover for each ModelE2 grid cell. This was necessary as sub-grid-scale ice fraction is accounted for in MAR, but a binary mask is required to define the elevation of ice cover for the elevation class scheme (Section 2.1.2). The mask results in the exclusion of small glaciers and ice caps, which contribute to 15-25\% of overall Greenland SMB (Bolch et al., 2013; Table S8). In this study, however, our main interest is in the contiguous GrIS. In sensitivity experiments, an elevation class scheme (Section 2.1.2) incorporates sub-grid-scale variations in ice sheet topography within the $50 \%$ mask from MAR. Below we describe relevant details of the Modele2 ice sheet surface model.

\subsubsection{ModelE2 Ice Sheet Surface Representation}

The land ice surface in ModelE2 is currently represented using a two-layer snow/ice model, described further in supporting information text $S 1$. The top layer contains up to 28.3 $\mathrm{cm}$ of snow at a density of $300 \mathrm{~kg} \mathrm{~m}^{-3}$, and $10 \mathrm{~cm}$ of ice. The bottom layer contains a fixed $2.9 \mathrm{~m}$ of ice. A simple densification scheme transforms excess snow into ice and passes excess ice to the oceans. This assumes an ice sheet in equilibrium, with net snow accumulation balanced by dynamic ice flow to the oceans (Text $\mathrm{S} 1$ ), a reasonable assumption 
for this study, which focuses only on surface processes. The model accounts for the transfer of energy and mass between the layers and evolution of subsurface temperatures (Hansen et al., 1983). Meltwater and rainwater are not retained or refrozen within the snow but are assumed to be transformed into runoff, which is routed to the oceans. Figure S1 provides a schematic of the ModelE2 surface model, including the elevation class scheme discussed in the following section.

\subsubsection{ModelE2 Elevation Class Scheme}

In a set of sensitivity runs, we employ an elevation class (EC) scheme (Fischer et al., 2014) to increase the resolution of the ModelE2 surface model to account for sub-grid-scale variations in GrIS topography; and by extension, temperature, melt, and runoff. Such variations are important to capture, given the relatively coarse ModelE2 resolution and the narrow ablation area (which is generally less than $150 \mathrm{~km}$ wide (Lucas-Picher et al., 2011; Noël et al., 2016).

The elevation class scheme defines a "grid" (a set of basis functions) over ice-covered areas by subdividing the GCM's grid along elevation contours defined by a high-resolution elevation dataset (in this case the MAR RCM $25 \mathrm{~km}$ resolution topography). This grid provides a computationally parsimonious way to represent functions that vary locally by elevation (e.g. runoff). The ModelE2 snow surface model is run on this grid. Each grid cell in the elevation grid corresponds to a single grid cell in the GCM grid and has a specific elevation that is within the range of elevations found in its "parent" GCM grid cell. We run simulations with two different configurations of this grid. In the first configuration (2 ECs) we use two elevations, for ice and non-ice areas derived from MAR, to isolate the impact of simply accounting for these different elevations. In the second configuration we use twenty ECs at fixed $200 \mathrm{~m}$ intervals, from $-100 \mathrm{~m}$ to $3,700 \mathrm{~m}$ above sea level, capturing the range of GrIS elevations. The choice of the number of elevation classes depends on the shape of the SMB curve along transects perpendicular to the ice edge (Fischer et al., 2014). The spacing of SMB observations along the Kangerlussuaq (K-) Transect measurement site in west Greenland (Smeets et al., 2018), and analysis of the MAR RCM (Franco et al., 2012) suggest that a $200 \mathrm{~m}$ vertical spacing is sufficient to capture sub-grid-scale SMB variability.

The elevation-dependent quantities temperature $(\mathrm{T})$, pressure $(\mathrm{P})$, and water vapor mixing ratio (q) are calculated by the atmospheric schemes in ModelE2 for the average elevation of each GCM grid cell. Therefore, at each coupling step, T, P, and q are 
downscaled to the elevation grid from the atmospheric fields according to the difference in elevation between each elevation grid cell and its corresponding atmospheric grid cell. Temperature is scaled assuming a lapse rate $(\gamma)$ of $8^{\circ} \mathrm{C} \mathrm{km}^{-1}$, which was chosen to allow temperature to vary smoothly across grid cells (Fischer et al., 2014) and is close to the average observed value of $\sim 7^{\circ} \mathrm{C} \mathrm{km}^{-1}$ for the Greenland ice sheet (e.g. Steffen \& Box, 2001). In section 3.2 we briefly explore sensitivity to lapse rate. Surface pressure is scaled according to the hydrostatic principle, assuming a constant atmospheric scale height of 6.8 km (Leung and Ghan, 1998; Marshall and Plumb, 2008). q is scaled according to variations in saturated specific humidity, assuming a constant relative humidity within each atmospheric grid cell. Scaling equations are provided in supporting information text S2.

Terms in the surface energy and mass balance equations, including net sensible and latent heat fluxes, upward longwave radiation and sublimation/evaporation are calculated on the elevation grid, and scaled to the atmospheric grid (Fig. S1; Fischer et al., 2014). Currently, surface albedo does not vary on the elevation grid. Downward radiative fluxes, and the amount and phase of precipitation are also not scaled with elevation. Although the effects of these factors are likely smaller than that of temperature, they could influence spatial variations in SMB, and this is a limitation of the current scheme.

\subsubsection{ModelE2 Surface Albedo Scheme}

The ModelE2 radiation scheme makes use of six visible and near infrared spectral bands to compute albedo. The current scheme employs a fixed broadband albedo of 0.8 over land ice only, which we use for control simulations. In this scheme, visible albedo is set to a value of 0.95 and near infrared albedo for the remaining five spectral bands is set to 0.5855 , yielding a broadband albedo of 0.8 . In a set of sensitivity experiments, we vary this fixed albedo over an interval from 0.4 to 0.8 , scaling the near infrared and visible albedo accordingly. Due to atmospheric effects, modeled albedo varies slightly by $<1 \%$ from the specified values. A correction of -0.02 is also applied to the average broadband albedo account for zenith angle effects.

We also test a time-variable albedo scheme over land ice. This scheme is currently used in ModelE2 for snow-covered areas on land, and was previously used over land ice in ModelE2, but yielded too much ablation of glacial surfaces. In this scheme, snow albedo $\left(\alpha_{\mathrm{s}}\right)$ is defined over six spectral bands and decays exponentially with time, in a modified form of 
the equation of Hansen et al. (1983, Eqn. 40):

$$
\alpha_{s, n}=\alpha_{m i n, n}+0.35 f_{n} e^{\frac{-a g e_{s}}{5}}
$$

where age $_{s}$ is the age of snow cover in days, $\alpha_{\mathrm{s}, \mathrm{n}}$ is the albedo for a specific spectral band (n), $\alpha_{\text {min, } \mathrm{n}}$ is the minimum snow albedo for each spectral band, and $f_{n}$ is a factor that varies with wavelength. Wavelength ranges and parameters for Eq. 4 are shown in Table S1 in the supporting information.

A simple scheme is used to age the snowpack and decrease snow age as a function of the amount of freshly fallen snow in a timestep. Snow age increases daily according to:

$$
\operatorname{age}_{s}(t+\Delta t)=0.98 \operatorname{age}_{s}(t)+1
$$

where $\Delta t$ is the length of a day. Snow age decreases with modelled precipitation according to:

$$
a g e_{s}(t+\Delta t)=a g e_{s}(t) e^{-\Delta P}
$$

where $\Delta \mathrm{P}$ is the amount of precipitation in $\mathrm{kg} \mathrm{m}^{-2}$ in time $\Delta \mathrm{t}$, which in this case is the $1800 \mathrm{~s}$ physics timestep.

For areas where the snow mass over ice is less than $10 \mathrm{~kg} \mathrm{~m}^{-2}$, albedo values are linearly interpolated between the albedo of snow and the albedo of ice as a function of snow amount, assuming a snow masking depth of $1 \mathrm{~cm}$ water equivalent (Hansen et al., 1983, Eqn. 39). The ice albedo values for each band are taken to be the same as the minimum snow albedo (Table S1, supporting information).

\subsection{MODIS albedo}

To further examine the impact of surface albedo we replace ModelE2 land ice albedo with a seasonally varying albedo derived from the Moderate Resolution Imaging Spectroradiometer (MODIS). For ease of use, we use the gridded MODIS dataset of Tedesco and Alexander (2013), regridded on the MAR grid, and based on the MOD10A1 version 5 product from the NASA Terra satellite (Hall et al., 2012), applying the MAR GrIS mask described in Section 2.1. These data subsequently regridded to the ModelE2 grid. We estimate that errors associated with regridding are less than 1\%, given that MODIS pixels 
along the perimeter of a MAR grid cell represent $\sim 8 \%$ of its area, leading to a $<4 \%$ error in daily albedo, and that averaging to the ModelE2 grid and across multiple years reduces errors to $<1 \%$. MOD10A1 broadband albedo over the $0.3-3.0 \mu \mathrm{m}$ range is computed from the daily MODIS observation that covers the largest fraction of a MODIS $463 \mathrm{~m}$ grid cell, and includes corrections MODIS wavelength bands effects, atmospheric effects and anisotropic scattering. We compute average MODIS June, July and August (JJA) albedos for 20012013 on the ModelE2 grid, and scale ModelE2 GrIS albedo to these fixed MODIS values for JJA. It should be noted that the MODIS period (2000-2013) coincides with a trend in declining GrIS surface albedo (Alexander et al., 2014; Tedesco et al., 2016), and the trend is anomalously high in MOD10A1 version 5 (Casey et al., 2017; Polashenski et al. 2015). The satellite-derived values are therefore lower than those for the 1996-2005 period. ModelE2 simulations with MODIS albedo therefore do not replicate 1996-2005 albedo variability, but rather illustrate the model response to seasonally and spatially varying albedo typical of 2001-2013.

\subsection{MAR Regional Climate Model}

The MAR simulation used here (MAR v3.5.2; Fettweis et al., 2017) has a $25 \mathrm{~km}$ spatial resolution and is forced at the lateral boundaries and ocean surface with outputs from the ECMWF ERA-40 (1958-1978) and ERA-Interim reanalysis (1979-2014) in order to most closely approximate observed GrIS conditions, allowing it to function as a gridded stand-in for observations. MAR combines the atmospheric scheme of Gallée and Schayes (1994) with a Soil Ice Snow Vegetation Atmosphere Transfer Scheme (SISVAT) of DeRidder and Gallée (1998), and the Crocus snow model of Brun et al. (1992, 1989). GrIS surface elevation is obtained from the digital elevation model of Bamber et al. (2013). Crocus includes a dynamic layering scheme with 35 snow and ice layers, fluxes of mass and energy between them, and aggregation of layers according to snow properties. Within each layer, snow grain size and shape are computed from temperature, liquid water content and temperature gradients. These quantities are used to determine surface albedo, transmittance through the snowpack, and snow densification. Liquid water is allowed to percolate and refreeze within the snowpack. Bare ice albedo is a function of surface meltwater production, ranging between 0.45 and 0.65 . MAR has been validated against in situ weather station data from the GrIS (Lefebre et al., 2003) and agrees well with remote sensing-derived surface melt (Fettweis et al., 2011), surface albedo (Alexander et al., 2014), and surface mass balance from ice cores and ablation 
stakes (Colgan et al., 2015). Further details about MAR can be found in Fettweis et al. (2017) and references therein. Here we use MAR to evaluate general patterns and biases in ModelE2 SMB, given its relatively high spatial resolution and accuracy relative to in situ and remote sensing observations. To compare with ModelE2, MAR outputs are re-gridded to the ModelE2 $2^{\circ}$ x $2.5^{\circ}$ grid using the conservative regridding scheme of Fischer et al. (2014) discussed in Section 2.1.2.

\subsection{Sublimation, Evaporation and Surface Roughness Length: ModelE2 vs. MAR}

To better understand differences between ModelE2 and MAR sublimation and latent heat fluxes (Section 3.4) we performed simulations with adjusted surface roughness length in ModelE2. MAR evaporation and sublimation are calculated from the humidity difference between the surface and the atmosphere, the surface wind speed, surface roughness lengths for moisture and momentum, boundary layer height, and bulk Richardson number (De Ridder \& Schayes, 1997, Section 2b). The formulation is quite similar in ModelE2 (Hansen et al., 1983, Section 2h). ModelE2 includes a wind "gustiness" correction (Schmidt et al., 2014), but the gustiness term is a small $(<1 \%)$ fraction of wind speed on average. A major difference between the two models, however, is in the calculation of surface roughness length.

For ModelE2, surface roughness length for momentum $\left(\mathrm{z}_{0, \mathrm{~m}}\right.$, in meters) for land and land ice is fixed and is calculated according to a modified form of Equation 55 of Hansen et al. (1983):

$$
z_{0, m}=0.6+0.041 \sigma^{0.71}
$$

where $\sigma$ is the standard deviation of sub-grid-scale topography (in meters) within a ModelE2 grid cell generated from a higher resolution topographic dataset (Hansen et al., 1983). The roughness length for moisture, $\mathrm{z}_{0, \mathrm{q}}$ for land and land ice is taken as proportional to $\mathrm{z}_{0, \mathrm{~m}}$ :

$$
z_{0, q}=z_{0, m} e^{-2}
$$

In MAR, GrIS surface roughness length is not based on large-scale topography, but depends on the contributions of the snow surface, snow density, sastrugi (undulations in the ice surface that result from wind redistribution), and snow erosion, as described by Gallée et al. (2001, 2013). Further details are provided in Section S3 of the supporting information. 
Values for momentum roughness length in MAR for Greenland are on the order of $10^{-3}$, while values for ModelE are on the order of $10^{\circ}$ (supporting information Figure S2). To evaluate the impact of bringing ModelE2 values closer to those from MAR, we conduct simulations for which $\mathrm{z}_{0, \mathrm{~m}}$ in ModelE2 over the GrIS is fixed at $5 \times 10^{-3}$, which is a minimum roughness length for smooth surfaces in ModelE2.

\section{Results and Discussion}

3.1 ModelE2 vs. MAR: SMB Comparison

We compared GrIS SMB and components from ModelE2 (with climatological and ocean forcing for 1996-2005) with MAR outputs for the same period. ModelE employs a free-running atmosphere, while MAR is forced with climate reanalysis data and agrees well with observations. The comparison here is thus intended to evaluate the ability of ModelE2 to simulate general patterns of SMB and the magnitude of SMB components. The average SMB for MAR over this period $\left(420 \pm 99 \mathrm{Gt} \mathrm{yr}^{-1}\right.$, with the range indicating interannual variability) is close to that from ModelE2 $\left(471 \pm 32 \mathrm{Gt} \mathrm{yr}^{-1}\right)$, despite the difference in spatial resolution between the two simulations (Fig. 1, Fig. 2, Table 1). ModelE2 (Fig. 1a) captures general features of GrIS SMB from MAR (Fig. 1b,c) with net ablation along the GrIS margins, maximum SMB in the southeast, and other maxima in the northwest. The spatial correlation between the two maps (weighting SMB for ice-covered-area) is fairly high $(\mathrm{r}=0.69)$. However, a regional comparison reveals spatial differences (Fig. 1d). SMB in ModelE2 is consistently lower than MAR across the GrIS interior, and ModelE2 exhibits a positive SMB bias along the margins. In some coastal grid cells, where ModelE2 underestimates ice elevation (Section 3.3), ModelE2 SMB is lower than MAR SMB. It should be noted that the fractional area of land ice is relatively small for these grid cells (Fig. S3 in the supporting information), so their overall contribution to GrIS SMB is small.

There are also substantial differences between ModelE2 and MAR SMB components (Fig. 2, Table 1; supporting material Table S2). MAR melt production is more than double

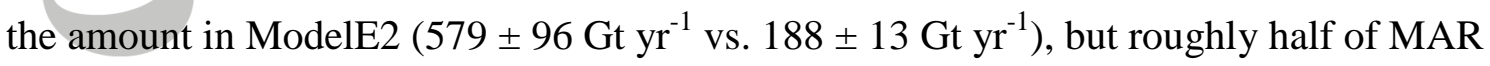
meltwater refreezes, while ModelE2 does not simulate refreezing. The lack of refreezing, coupled with higher amounts of rainfall $\left(66 \pm 8 \mathrm{Gt} \mathrm{yr}^{-1}\right.$ vs. $\left.40 \pm 8 \mathrm{Gt} \mathrm{yr}^{-1}\right)$ results in ModelE2 runoff estimates that are close to those of MAR (340 $\pm 73 \mathrm{Gt} \mathrm{yr}^{-1}$ for ModelE2 vs. $254 \pm 17$

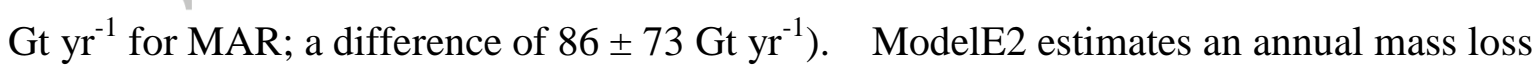




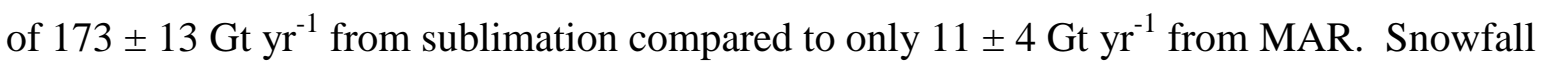
is also larger in ModelE2 ( $832 \pm 46 \mathrm{Gt} \mathrm{yr}^{-1}$ vs. $730 \pm 45 \mathrm{Gt} \mathrm{yr}^{-1}$ for MAR) by $14 \pm 9 \%$. The difference in melt is the largest of the components, representing $93 \pm 45 \%$ of MAR SMB, followed by refreezing $(64 \pm 35 \%)$, sublimation (39 $\pm 13 \%)$ and snowfall (24 $\pm 19 \%)$ (supporting information Table S2).

Spatial differences in SMB are controlled by SMB component differences (Fig. 3, Figure S4). Lower ModelE2 SMB at high elevations (Fig. 1d) results from lower precipitation and to a lesser degree higher sublimation relative to MAR (Fig. 3d,a; supporting information Fig. S4a,c). Higher SMB in ModelE2 at lower elevations is a product of lower runoff and higher precipitation in roughly equal amounts, counteracted by higher Modele2 sublimation (Fig. 3b,a; supporting information Fig. S4a,b). ModelE2 melt is also substantially lower at lower elevations where most GrIS melting occurs (Fig. 3c).

To understand how the observed biases in components might be affected by differences in atmospheric circulation, we ran a simulation in which ModelE2 winds were nudged to align with those of the MERRA-2 reanalysis (E2-Nudged). The nudged simulation captures interannual variability in surface pressure $(\mathrm{r}=0.89)$ and temperature $(\mathrm{r}=0.65)$ from MAR reasonably well (supporting information Fig. S5), as well as SMB components except for sublimation + evaporation (which is very small in MAR) (Fig. S6), but the agreement is poorer for surface energy balance components (Table S4), likely due to model biases in these

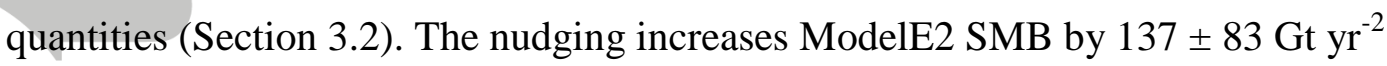

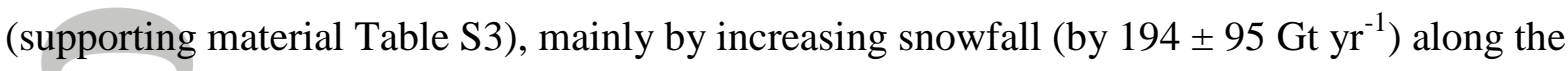
southwest and northeast margins (supporting material Figs. S7 and S8). Mean runoff and sublimation are not substantially affected (supporting material Figs. S7 and S8, Table S3). The analysis suggests that forcing ModelE2 to better represent atmospheric variability does not substantially affect the conclusions of this study.

\subsection{ModelE2 vs. MAR: Surface Energy Balance}

To better understand potential reasons for differences in melt, runoff, and sublimation we examined components of the surface energy balance (SEB). Differences between surface energy fluxes simulated by ModelE2 and MAR are fairly small on average (Fig. 4, Table S5, supporting information), but there are larger spatial differences. Incoming shortwave (SW) radiation is 
lower in ModelE2 in northern Greenland and along the coast, while the opposite is true for incoming longwave (LW) radiation (Fig $4 \mathrm{a}, \mathrm{b}$ ). Figure $4 \mathrm{~h}$ suggests that these differences may be associated with cloud cover, as a greater cloud fraction corresponds to lower incoming SW and higher LW radiation, an effect that is found in observations (e.g. van Tricht et al., 2016; Miller et al., 2017). The largest mean differences in energy flux terms are from latent and sensible heat flux (Fig. 4 c,g). These differences are consistent with global ModelE2 latent and sensible heat biases identified by Schmidt et al. (2014), although that study did not include a regional assessment. Sensible and latent heat fluxes are not necessarily complementary (e.g. Lund et al., 2017; van den Broeke et al., 2011), but in this case they happen to be. The similar and opposing patterns of sensible and latent heat flux differences are likely associated with differences in simulated turbulence, which affects both variables. This effect is explored further in Section 3.6. The average surface air temperature (at $10 \mathrm{~m}$ above the surface) difference between the two models is fairly small overall $\left(0.4 \pm 1^{\circ} \mathrm{C}\right)$, with larger local differences of up to $\sim 5^{\circ} \mathrm{C}$ (Fig. 4d).

The spatial pattern of temperature differences is in some locations consistent with inter-model runoff differences (although the overall spatial correlation is low: $r=0.1$ ); warmer coastal grid cells in particular exhibit higher melt, and melt is underestimated for cooler grid cells slightly further inland. These differences cannot fully explain the large differences in some of the SMB components (e.g. melt and sublimation). To further understand potential sources of these differences and potential improvements to ModelE2, we discuss changes to the ModelE2 representation of the GrIS surface in the following sections.

\subsection{Effect of Elevation Classes on ModelE2 SMB}

Spatial resolution is often cited as an important factor in simulations of GrIS SMB (e.g. Cullather et al., 2014; Ettema et al., 2009; Lucas-Picher et al., 2012). Adding surface elevation classes is a way to increase the spatial resolution of the surface model, at low cost. Adding two elevation classes (ECs) to the ModelE2 control simulation (E2-2ECs vs. E2control), separates ice elevation from the elevation of other grid cell surfaces. This has a fairly small impact on GrIS-wide SMB, raising SMB by $63 \pm 91 \mathrm{Gt} \mathrm{Yr}^{-1}$, primarily through a decrease in runoff (Fig. 2, Table 1). Figure 5 illustrates the reasons for this effect. In the E2control a single average elevation is used for each grid cell. The elevation of land ice is generally greater than that of other surface types, and the 2EC simulation allows the ice 
elevation to be specified independently, resulting in a higher ice elevation (Fig. 5a). This produces colder surface air temperatures (Fig. 5c), a decrease in melt, and an increase in SMB (Fig. 5b). Changes in SMB components at higher elevations are minor.

In the twenty elevation class simulation (E2-20ECs), SMB is lower than in the E2-

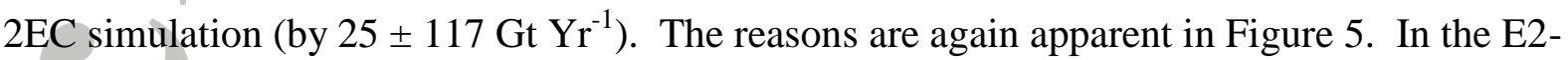
2EC simulation, the average ice elevation difference relative to E2-control is the same as in the E2-2EC simulation (Fig. 5a). However, the E2-20EC simulation captures multiple subgrid-cell ice elevations, capturing nonlinear variations in temperature and runoff. The overall effect is a slight cooling of the surface (Fig. 5e), and lower SMB relative to the 2EC simulation, with a mixed spatial effect (Fig. 5d). On average, energy balance components, temperatures, and cloud fraction are not substantially affected by the addition of elevation classes (Table S5; Table S6, supporting information) indicating a small impact on surfaceatmosphere feedbacks.

The net effect of including ECs is to produce realistic local SMB values, with relatively small GrIS-wide SMB changes. Other factors, such as surface albedo, could potentially modulate the SMB response (Section 3.5). The specified lapse rate (which is spatially and temporally variable; Fausto et al., 2009) is another potential modulating factor. We tested the sensitivity of our results to lapse rates of $6{ }^{\circ} \mathrm{C} \mathrm{km}^{-1}$ and $10^{\circ} \mathrm{C} \mathrm{km}^{-1}$, but found only small effects on SMB and energy balance components within the range of interannual variability (supporting information Table S7; Fig. S9).

A factor that is not substantially improved with ECs is precipitation (Fig. 2; Table 1), which cannot be easily scaled according to elevation, but is affected by model resolution (e.g. Franco et al., 2012; Ettema et al., 2009). We evaluated a set of MAR simulations at lower spatial resolution (50 and $75 \mathrm{~km}$ ) to test resolution effects (Section S4). The decrease in spatial resolution increases precipitation (consistent with Franco et al., 2012), although relative to the magnitude of precipitation changes are small $(<10 \%$ ice-sheet wide; Figs. S10 and S11; Table S8). The $75 \mathrm{~km}$ simulation enhances melt and runoff (by 70\%), likely due to a widening of the ablation zone due to a coarser resolution (similar to E2-control). Other studies have found larger precipitation effects (Ettema et al., 2009; Cullather et al., 2014; Lucas-Picher et al., 2012; Franco et al., 2012). Understanding these effects still a challenge for GCM simulations. They are particularly important and should be the subject of additional work. 
Surface albedo plays an important role in evolution of GrIS melt and runoff (e.g. Alexander et al., 2014; Helsen et al., 2017; Tedesco et al., 2008; van Angelen et al., 2012). We tested the impact of a spatially and temporally variable surface albedo on ModelE2simulated SMB by (1) replacing the fixed surface albedo in the 20 EC simulations with daily average MODIS albedo (2000-2013) for June July and August (E2-Sat- $\alpha$ ), and (2) utilizing the age-dependent scheme described in Section 2.1.3 (E2- $\alpha-f($ age $)$ ).

Using MODIS albedo in the E2-Sat- $\alpha$ simulation captures lower albedo close to the coast, where melt and bare ice exposure during summer darken the surface (Fig. 6a). The effect on average reflected shortwave radiation is small $\left(-3 \pm 2 \mathrm{~W} \mathrm{~m}^{-2}\right)$ and there is little change in other energy balance terms, cloud cover or surface temperature (supporting information Table S5). The changes are also small relative to interannual June through August variability (supporting information Table S6), but JJA land-ice albedo values for individual grid cells are lower by up to $\sim 0.4$ (supporting information Fig. S12a). These local and seasonal changes reduce SMB by $133 \pm 106 \mathrm{Gt} \mathrm{Yr}^{-1}$ due to an increase of melt and runoff; melt increases by $148 \pm 45 \mathrm{Gt} \mathrm{Yr}^{-1}$ to $278 \pm 45 \mathrm{Gt} \mathrm{Yr}^{-1}$ relative to the E2-20ECs simulation (Fig. 2, Table 1, Fig. 6b). The spatial pattern of SMB is also closer to that of $\operatorname{MAR}(r=0.78$ for the spatial correlation vs. $r=0.69$ relative to E2-control); capturing an ablation area along the west GrIS coast (Fig. S12c).

The age-dependent albedo scheme captures the spatial variability in MODIS albedo ( $\mathrm{r}$ = 0.997; Fig. 6c), but lowers albedo below the MODIS values (supporting information Fig. $\mathrm{S} 12 \mathrm{~b}$ ), especially at higher elevations. Changes are small for surface temperature, cloud cover and energy balance components (Table S5). SMB is reduced substantially (again in areas of lower albedo Fig. 6d, Fig. S12d) by $266 \pm 131 \mathrm{Gt} \mathrm{Yr}^{-1}$ relative to E2-20ECs with melt increasing by $240 \pm 41 \mathrm{Gt} \mathrm{Yr}^{-1}$ to $370 \pm 57 \mathrm{Gt} \mathrm{Yr}^{-1}$ (Fig. 2, Table 1, Fig. 6d). The agedependent scheme, developed for seasonal snow cover, likely overestimates the decline of snow albedo with snow age in the pristine GrIS climate, where cold temperatures prevent rapid metamorphism of snow grains and impurity concentrations are low (e.g. Tedesco et al., 2016).

Interestingly, although both simulations reduce local differences, neither of them

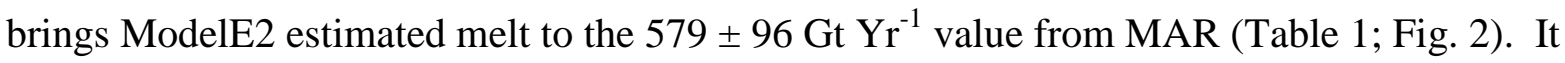


is likely that a key factor in the larger amount of melting in MAR is the presence of melt and rainwater refreezing and retention, absent in ModelE2, which both warm the snowpack (e.g. Humphrey et al., 2012), increasing the likelihood of melt events.

\subsection{Combined Effect of Elevation Classes and Varying Surface Albedo}

To further understand how surface albedo and elevation classes interact, we performed sensitivity studies altering specified fixed ice sheet-wide albedo values over a range from 0.4 to 0.7 . In each of these simulations, the surface model is run simultaneously over several sets of elevation classes corresponding to the $1 \mathrm{EC}$ (control), $2 \mathrm{EC}$, and $20 \mathrm{EC}$ cases. In these simulations the $1 \mathrm{EC}$ and $2 \mathrm{EC}$ simulations are effectively run offline while the atmosphere responds to the $20 \mathrm{EC}$ simulation. This increases computational efficiency but ignores surface-atmosphere feedbacks for the $1 \mathrm{EC}$ and $2 \mathrm{EC}$ cases. These feedbacks are generally within the range of atmospheric variability as evidenced by the small effect of ECs on energy balance components and fields such as precipitation (Table S5 and S6; Table 1).

For these simulations, there is a fairly linear relationship between fixed ice sheet surface albedo and average GrIS SMB, with SMB becoming negative for the lowest albedo values (Fig. 7). Adding 2 ECs raises average SMB, and 20 ECs lower SMB relative to the 2 EC case for all albedo values. However, the effect of elevation classes scales with SMB: the lower the albedo, the larger the impact of elevation classes. For example, for an albedo of 0.4 , SMB is reduced by $198 \pm 15 \mathrm{Gt} \mathrm{Yr}^{-1}$ (in the 20EC simulation relative to the 1EC simulation) but the reduction is only $44 \pm 6 \mathrm{Gt} \mathrm{Yr}^{-1}$ for an ice sheet albedo of 0.8 (Fig. 7; Table 1). Note that although the interannual variability increases with decreasing SMB as shown in Fig. 7 and supporting material Table S9, the interannual variability on the difference is small because atmospheric forcing is the same for the different EC configurations. The average SMB values for the 1 and 2 elevation class cases are somewhat different from those in previous sections given that atmospheric conditions are for the $20 \mathrm{EC}$ case. This analysis illustrates that under different atmospheric or surface conditions, incorporating elevation classes into a simulation could potentially have a stronger or weaker impact on SMB, modulating the response of SMB to declining surface albedo, for instance, by better capturing marginal surface topography. Incorporating elevation classes along with dynamic surface albedo could therefore play an important role in long-term simulations of GrIS SMB. 
3.6 ModelE2 Sublimation and Surface Roughness Length

Sublimation (and/or evaporation) from the surface is an additional surface-related process marginally affected by changes in surface albedo and elevation classes. Model simulations generally estimate sublimation to be a small fraction of GrIS SMB (e.g. Cullather et al., 2014) and given a lack of available observations, it has been given little attention (Boisvert et al., 2017). Sublimation represents a substantial portion of SMB in ModelE2 (34\% for the E2-control simulation) as opposed to MAR (1\%; Table 1). ModelE2 sublimation is much larger than that simulated by other GCMs and RCMs in the intercomparison of Cullather et al. (2014). A recent satellite- derived estimate places GrIS

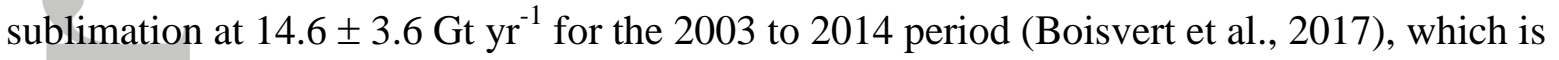

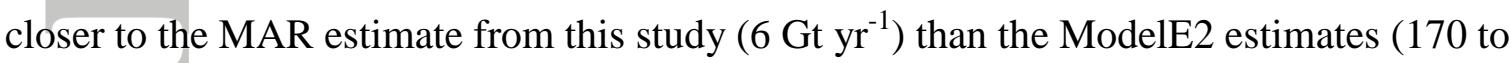
$180 \mathrm{Gt} \mathrm{Yr}^{-1}$ ), although an earlier estimate from Box and Steffen (2001) obtained from in situ

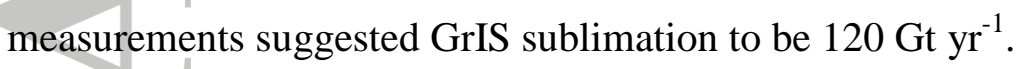

One possible explanation for these differences may lie in model estimates of surface roughness length. It is not very well constrained for the GrIS, and is sometimes adjusted in models to examine model sensitivity (e.g. Carlson et al., 2009). For the same temperature or humidity difference a higher surface roughness length will lead to increased sensible or latent heat flux. As noted in Section 2.4, MAR surface roughness lengths are on the order of $10^{-3}$ $\mathrm{m}$ (closer to those of a smooth flat surface; Brutsaert, 1982, Table 5.1), while those for ModelE2 are on the order of $10^{\circ} \mathrm{m}$ (Fig. S2, supporting information). To understand how higher roughness length in ModelE2 might influence evaporation, we ran a simulation with the effect of topographic variability on surface roughness length removed (E2- $\mathrm{z}_{0}$-adj). In this simulations the roughness length for ice is equal to the minimum roughness length of $5 \times 10^{-3}$ $\mathrm{m}$.

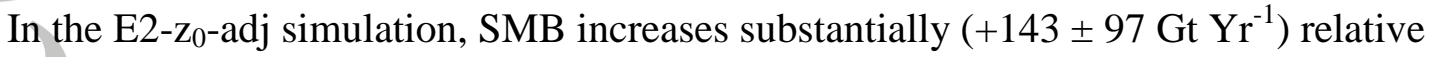
to the E2-20ECs simulation. Sublimation and evaporation are substantially reduced (by $\sim 50 \%$ ) from $173 \pm 13 \mathrm{Gt} \mathrm{Yr}^{-1}$ to $94 \pm 6 \mathrm{Gt} \mathrm{Yr}^{-1}$ (Fig. 2, Table 1). Other factors also contribute to the SMB change but the changes are small relative to the interannual variability (Table 1). The largest changes in SMB occur along the coast, where sublimation is also generally higher (Fig. S13a). There are also substantial changes in latent and sensible heat fluxes, bringing values closer to MAR (supporting information Tables S5 \& S6). We also 
tested the sensitivity to simulations in which roughness length over the GrIS is fixed at $3.5 \mathrm{x}$ $10^{-3} \mathrm{~m}$ and $0.01 \mathrm{~m}$, roughly the range of roughness lengths for the GrIS in MAR. These changes have a relatively minor effect relative to the change in topographic dependence (Table S10; Fig. S13, S14), suggesting that in addition to the large influence of the topographic roughness length effect, other as yet unidentified factors may be responsible for the inter-model differences.

\section{Conclusions}

The experiments discussed above indicate the importance of improving the Greenland ice sheet surface representation despite an agreement of within 5\% between ModelE2 and MAR for GrIS average SMB, and the ability of the GCM to simulate spatial patterns of SMB with a freely evolving atmospheric circulation. An investigation of ModelE2 vs. MAR SMB components reveals large differences: ModelE2 melt is half that of MAR, but a lack of refreezing results in a similar amount of runoff. ModelE2 sublimation is more than 10 times that of MAR, and precipitation is higher by $\sim 25 \%$. On average, differences in surface energy balance terms and surface air temperature are small; larger spatial differences may be associated with differences in the representation of atmospheric processes.

We find that sensitivity tests adding elevation classes (EC) do not substantially impact GrIS-wide SMB or its components, or the surface energy balance relative to the control simulation, but ECs do correct local SMB errors. The influence of ECs is also enhanced by other factors such as surface albedo, indicating their potential importance in long-term simulations. ECs are also important in enabling GCMs to produce a higher-resolution representation of SMB necessary for accurate simulation of the ice sheet dynamic response (e.g. Schlegel et al., 2015). It should be noted that the simulations performed here do not include factors such as sub-grid-scale variations in surface albedo, downward radiative fluxes, and precipitation phase. If employed in conjunction with ECs, these factors could potentially enhance simulated mass loss.

Our findings indicate, as other studies have shown, that albedo plays a key role in simulated SMB. Incorporating a realistic spatially and temporally varying surface albedo into ModelE2 while reducing average albedo by only $~ 2-3 \%$ doubled simulated melt. Being able to simulate decadal variations in surface albedo (e.g. Tedesco et al., 2016), could therefore have a large impact on simulated past, present, and future SMB variability. The age-dependent scheme currently employed over seasonal snow on land in ModelE2 
underestimates GrIS albedo. This explains the high melt rate over land ice in ModelE2 in previous simulations and indicates the need for a more physically-based representation of GrIS albedo in ModelE2. Integration and testing of such a scheme in ModelE2 is currently in development.

Although sublimation is considered to be a minor GrIS SMB term, it represents a substantial component of SMB in ModelE2. Removing the dependence of surface roughness length on sub-grid-scale topography in ModelE2 reduces simulated sublimation by $\sim 50 \%$ on average. Given that few studies have investigated the role of surface roughness length in GrIS SMB, further work is needed to evaluate this parameter and improve the simulations as necessary, as these changes could lead to large changes in simulated SMB.

Meltwater refreezing is a large component of SMB in MAR and other models (e.g. Steger et al., 2017; van den Broeke et al., 2016), accounting for roughly half of meltwater production, but is not accounted for in ModelE2. Refreezing warms the snowpack, providing energy for further melting. An improved representation of the ice sheet surface in ModelE2, including a simple refreezing scheme, is currently under development, and the impact of this new representation will be discussed in future publications.

There are also differences in precipitation and cloud cover between ModelE2 and MAR that may result from differences in model resolution and parameterizations for atmospheric processes in both models. It is possible that these differences, as well as a portion of the differences in melt and runoff could result from differences in representation of the atmosphere. Phenomena such as large-scale atmospheric circulation changes (e.g. Fettweis et al., 2013; Hanna et al., 2018), cloud cover (e.g. Hofer et al., 2017; van Tricht et al., 2017), and atmospheric river events (Mattingly et al., 2018) can impact GrIS SMB. There is still, however, uncertainty in the role of atmospheric drivers in GrIS SMB. For example, Hofer et al. (2017) estimate a $27 \mathrm{Gt} \mathrm{yr}^{-1}$ increase in melt for each percent reduction in GrIS summer cloud cover, while van Tricht et al. (2017) find a that runoff increases by $\sim 30 \%$ in the presence of clouds. Previous studies (e.g. Ettema et al., 2009; Lucas-Picher et al., 2012) have also shown that changing the spatial resolution of the atmospheric simulation can influence modeled precipitation rates.

Our tests to examine the impact of nudging winds in ModelE2 moderately increased precipitation, but did not dramatically change other SMB components. MAR simulations in which spatial resolution was reduced produced moderate increases in precipitation and more 
substantial changes to melt in the lowest resolution $(75 \mathrm{~km})$ simulation. Future work (e.g. in which MAR is forced with ModelE2, and ModelE2 is run at a higher spatial resolution) is necessary in order to provide further insight into the role of atmospheric processes on simulated SMB. What we have shown here is that capturing surface processes in GCM simulations plays an important role in simulating GrIS SMB. We have also shown that care should be taken to accurately represent these processes in simulations of ice sheet mass change, particularly with regard to capturing components and spatial patterns of SMB, as different processes and regions may respond differently to future changes in climate.

\section{Acknowledgments, Models, and Data}

Outputs from the ModelE2 GCM used here and temporally averaged fields and timeseries for the MAR v3.9 simulations used here are provided at https://data.giss.nasa.gov/modelE/greenland-smb/. The ModelE2 code used here is not a publicly released version of ModelE, but resides within the ModelE development repository (ModelE tag: palexander/ec2_albedo2), available through https://simplex.giss.nasa.gov/gcm/ or upon request from the corresponding author. MARv3.5.2 outputs are publicly available at ftp://ftp.climato.be/fettweis/MARv3.5/Greenland/, and MARv3.5.2 source code at $\mathrm{ftp} / / / \mathrm{ftp} . c l i m a t o . b e / f e t t w e i s / M A R v 3.5 / . \mathrm{src} /$. ECMWF reanalyses used to force MAR were downloaded from http://apps.ecmwf.int/datasets/. The regridding software of Fischer et al. (2014) is publicly available through https://github.com/citibeth/icebin/. Further details can be obtained by contacting E. Fischer (elizabeth.fischer@columbia.edu). P. Alexander, E.

Fischer, M. Tedesco, and A. N. LeGrande acknowledge support from the NASA Modeling, Analysis, and Prediction (MAP) program award 16-MAP16-0137: NASA NRA \#: NNH16ZDA001N-MAP. (Understanding and quantifying the links between ice sheet and glacial albedo, surface mass balance and atmospheric fluxes through improved NASA GISSE2 simulations). E. Fischer and S. Nowicki also acknowledge support from the NASA MAP program. M. Tedesco and P. Alexander acknowledge support from the NASA Cryosphere program (NNX17AH04G). M. Tedesco acknowledges support from the NSF Office of Polar Programs (OPP-1713072). P. Alexander was also supported by an appointment to the NASA Postdoctoral Program (NPP) at the NASA Goddard Institute for Space Studies, administered by the Universities Space Research Association and Oak Ridge Associated Universities under contract with NASA. Resources supporting this work were provided by the NASA High-End Computing Program through the NASA Center for Climate Simulation (NCCS) at the Goddard Space Flight Center. We thank NASA GISS for institutional support. The authors 
thank G. Russell, I. Aleinov, L. Nazarenko, and J. Nusbaumer for advice and suggestions on running the ModelE2 GCM, and S. E. Moustafa for discussions regarding MAR and Greenland surface albedo.

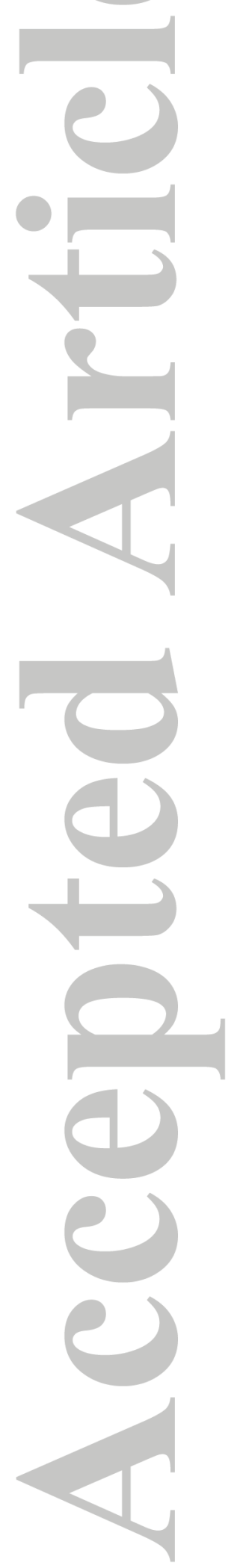




\section{References}

Alexander, P. M., Tedesco, M., Fettweis, X., van de Wal, R. S. W., Smeets, C. J. P. P., \& van den Broeke, M. R. (2014) Assessing spatio-temporal variability and trends in modelled and measured Greenland ice sheet albedo (2000-2013). The Cryosphere, 8(6), 2293-2312. doi:10.5194/tc-8-2293-2014

Bamber, J. L., Griggs, J. A., Hurkmans, R. T. W. L., Dowdeswell, J. A., Gogineni, S. P., Howat, I., et al. (2013) A new bed elevation dataset for Greenland. The Cryosphere, 7(2), 499-510. doi:10.5194/tc-7-499-2013

Bindschadler, R. A., Nowicki, S., Abe-Ouchi, A., Aschwanden, A., Choi, H., Fastook, J. et al. (2013) Ice-sheet model sensitivities to environmental forcing and their use in projecting future sea level (the SeaRISE project). Journal of Glaciology, 59(214), 195-224.

doi:10.3189/2013JoG12J125

Boisvert, L. N., Lee, J. N., Lenaerts, J. T. M., Noël, B., van den Broeke, M. R., \& Nolin, A. W. (2017) Using remotely sensed data from AIRS to estimate the vapor flux on the Greenland ice sheet: Comparisons with observations and a regional climate model. Journal of Geophysical Research: Atmospheres, 122, 202-229, doi:10.1002/2016JD025674

Bolch, T., Sandberg Sørensen, L., Simonsen, S. B., Mølg, N., Machguth, H., Rastner, P., and Paul, F. (2013) Mass loss of Greenland's glaciers and ice caps (2003-2008) revealed from ICESat laser altimetry. Geophysical Research Letters, 40, 875-881, doi: 10.1002/grl.50270.

Box, J. E. \& Steffen, K. (2001) Sublimation on the Greenland ice sheet from automated weather station observations. Journal of Geophysical Research: Atmospheres, 106(D24), 33965-33981. doi: 10.1029/2001JD900219

Brun, E., Martin, E., Simon, V., Gendre, C., \& Coleou, C. (1989) An energy and mass model of snow cover suitable for operational avalanche forecasting. Journal of Glaciology, 35(121), 333-342.

Brun, E., David, P., Sudul, M., \& Brunot, G. (1992) A numerical model to simulate snowcover stratigraphy for operational avalanche forecasting. Journal of Glaciology, 38(128), 1322.

Brutsaert, W. (1982) Evaporation into the atmosphere: theory, history, and applications. Dordrecht, Netherlands: Springer Netherlands.

Carlson, A. E., Anslow, F. S., Obbink, E.A., LeGrande, A. N., Ullman, D. J., and Licciardi, J. M. (2009) Surface-melt driven Laurentide Ice Sheet retreat during the early Holocene. Journal of Geophysical Research, 36, L24502, doi: 10.1029/2009GL040948.

Church, J. A., Clark, P. U., Cazenave, A., Gregory, J. M., Jevrejeva, S., Levermann, A., et al. (2013) Sea level change. In T. F. Stocker, D. Qin, G.-K. Plattner, M. Tignor, S. K. Allen, J. Boschung, et al. (Eds.), Climate change 2013: the physical science basis. Contribution of working group I to the Fifth Assessment Report of the Intergovernmental Panel on Climate Change. (pp. 1137-1216). Cambridge, UK and New York, NY, USA: Cambridge University Press.

Colgan, W., Box, J. E., Andersen, M. L., Fettweis, X., Csathó, B., Fausto, R. S., et al. (2015) Greenland high-elevation mass balance: inference and implication of reference period (196190) imbalance. Annals of Glaciology, 56(70), 105-117. doi:10.3189/2015AoG70A967

Cullather, R. I., Nowicki, S. M. J., Zhao, B., \& Suarez, M. J. (2014), Evaluation of the surface representation of the Greenland ice sheet in a general circulation model. Journal of 
Climate, 27(13), 4835-4856. doi:10.1175/JCLI-D-13-00635.1

De Ridder, K., \& Gallée H. (1998), Land surface-induced regional climate change in southern Israel. Journal of Applied Meteorology, 37, 1470-1485.

DeRidder, K. \& Schayes, G. (1997), The IAGL land surface model. Journal of Applied Meteorology, 36, 167-182.

Edwards, T. L., Fettweis, X., Gagliardini, O., Gilet-Chaulet, F., Goelzer, H., Gregory, J. M., et al. (2014) Effect of uncertainty in surface mass balance-elevation feedback on projections of the future sea level contribution of the Greenland ice sheet. The Cryosphere, 8, 195-208. doi: $10.5194 /$ tc- $8-195-2014$

Enderlin, E. M., Howat, I. M., Jeong, S. Noh, M.-J., van Angelen, J. H., \& van den Broeke, M. R. (2014) An improved mass budget for the Greenland ice sheet. Geophysical Research Letters, 41(3), 866-872. doi:10.1002/2013GL059010

Eyring, V., Bony, S., Meehl, G. A., Senior, C. A., Stevens, B., Stouffer, R. J., \& Taylor, K. E. (2016) Overview of the Coupled Model Intercomparison Project Phase 6 (CMIP6) experimental design and organization. Geoscientific Model Development, 9(5), 1937-1958. doi: 10.5194/gmd-9-1937-2016.

Fausto, R. S., Ahlstrøm, A. P., van As, D., Bøggild, C., and Johnsen, S. J. (2009) A new present-day temperature parameterization for Greenland. Journal of Glaciology, 55, 189, 95105.

Fettweis, X., Gallée, H., Lefebre, F., \& van Ypersele, J.-P. (2005) Greenland surface mass balance simuated by a regional climate model and comparison with satellite-derived data in 1990-1991. Climate Dynamics, 24(6), 623-640. doi:10.1007/s00382-005-0010-y

Fettweis, X., Tedesco, M., van den Broeke, M., \& Ettema, J. (2011) Melting trends over the Greenland ice sheet (1958-2009) from spaceborne microwave data and regional climate models. The Cryosphere, 5(2), 359-375. doi:10.5194/tc-5-359-2011

Fettweis, X., Hanna, E., Lang, C., Belleflamme, A., Erpicum, M., \& Gallée, H. (2013) Brief communication: "Important role of the mid-tropospheric atmospheric circulation in the recent surface melt increase over the Greenland ice sheet." The Cryosphere, 7, 241-248. doi:10.5194/tc-7-241-2013.

Fettweis, X., Box, J. E., Agosta, C., Amory, C., Kittel, C., Lang, C., et al. (2017) Reconstructions of the 1900-2015 Greenland ice sheet surface mass balance using the regional climate MAR model. The Cryosphere, 11(2), 1015-1033. doi:10.5194/tc-11-10152017

Fischer, R., Nowicki, S., Kelley, M., \& Schmidt, G. A. (2014) A system of conservative regridding for ice-atmosphere coupling in a general circulation model (GCM). Geoscientific Model Development, 7(3), 883-907. doi:10.5194/gmd-7-883-2014

Franco, B., Fettweis, X., Lang, C., and Erpicum, M. (2012) Impact of spatial resolution on the modelling of the Greenland ice sheet surface mass balance between 1990-2010, using the regional climate model MAR. The Cryosphere, 6, 695-711, doi: 10.5194/tc-6-695-2012.

Gallée, H. \& Schayes, G. (1994) Development of a three-dimensional meso- $\gamma$ primitive equation model: katabatic winds simulation in the area of Terra Nova Bay, Antarctica. Monthly Weather Review, 122(4), 671-685.

Gallée, H., Guyomarc'h, G., \& Brun, E. (2001) Impact of snow drift on the Antarctic Ice Sheet surface mass balance: possible sensitivity to snow-surface properties. Boundary-Layer 
Meteorology, 99(1), 1-19. doi: 10.1023/A:1018776422809

Gallée, H., Trouvilliez, A., Agosta, C., Genthon, C., Favier, V., \& Naaim-Bouvet, F. (2013) Transport of snow by the wind: a comparison between observations in Adélie Land, Antarctica, and simulations made with the regional climate model MAR. Boundary-Layer Meteorology, 146(1), 133-147. doi: 10.1007/s10546-012-9764-Z

Gelaro, R., McCarty, W., Suarez, M., Todling, R., Molod, A., Takacs, L., et al. (2017) The Modern-Era Retrospective Analysis for Research and Applications, Version 2 (MERRA-2). J. Climate, 30, 5419-5454.

Goelzer, H., Huybrechts, P., Fürst, J. J., Nick, F. M., Andersen, M. L., Edwards, T. L., et al. (2013) Sensitivity of Greenland ice sheet projections to model formulations. Journal of Glaciology, 59(216), 733-749. doi:10.3189/2013JoG12J182

Gomez, N., Pollard, D., \& Holland, D. (2015) Sea-level feedback lowers projections of future Antarctic Ice-Sheet mass loss. Nature Communications, 6(1). doi:10.1038/ncomms9798

Hall, D. K., Salomonson, V. V., \& Riggs, G. A. (2012) MODIS/Terra snow cover daily L3 global 500 m grid, version 5 [Tiles h15v02, h16v02, h17v02, h16v01, h16v00, h17v00]. Boulder, CO: National Snow and Ice Data Center.

Hanna, E., Fettweis, X., and Hall, R. J. (2018) Brief communication: Recent changes in summer Greenland blocking captured by none of the CMIP5 models. The Cryosphere, 12, 3287-3292, doi: 10.5194/tc-12-3287-2018.

Hansen, J., Russell, G., Rind, D., Stone, P., Lacis, A., Lebedeff, S., Ruedy, R., \& Travis, L. (1983) Efficient three-dimensional global models for climate studies: models I and II.

Monthly Weather Review, 111(4), 609-662.

Helsen, M. M., van de Wal, R. S. W., Reerink, T. S., Bintanja, R., Madsen, M. S., Yang, S., $\mathrm{Li}$, Q., \& Zhang, Q. (2017) On the importance of the albedo parameterization for the mass balance of the Greenland ice sheet in EC-Earth. The Cryosphere, 11(4), 1949-1965. doi:10.5194/tc-11-1949-2017

Hofer, S., Tedstone, A. J., Fettweis, X., and Bamber, J. L. (2017) Decreasing cloud cover drives the recent mass loss on the Greenland ice sheet. Science Advances, 3, e1700584, doi: 10.1126/sciadv.1700584.

Humphrey, N. F., Harper, J. T., \& Pfeffer, W. T. (2012) Thermal tracking of meltwater retention in Greenland's accumulation area. Journal of Geophysical Research , 117, F01010, doi: $10.1029 / 2011 \mathrm{JF} 002083$.

Khan, S. A., Aschwanden, A., Bjørk, A. A., Wahr, J., Kjeldsen, K. K., \& Kjær, K. H. (2015) Greenland ice sheet mass balance: a review. Reports on Progress in Physics, 78(4), 046801, doi:10.1088/0034-4885/78/4/046801

Kim, D., Sobel, A. H., Del Genio, A., Chen, Y.-H., Carmago, S. J., Yao, M.-S., Kelley, M., and Nazarenko, L. (2012) The tropical subseasonal variability simulated in the NASA GISS general circulation model. Journal of Climate, 25, 4641-4659, doi: 10.1175/JCLI-D-1100447.1.

Langen, P. L., Fausto, R. S., Vandecrux, B., Mottram, R. H., \& Box, J. E. (2017) Liquid water flow and retention on the Greenland ice sheet in the regional climate model HIRHAM5: Local and large-scale impacts. Frontiers in Earth Science, 4, 110. doi:10.3389/feart.2016.00110

Lefebre, F., Gallée, H., van Ypersele, J.-P., \& Greuell, W. (2003) Modeling of snow and ice 
melt at ETH Camp (west Greenland): A study of suface albedo. Journal of Geophysical Research, 108(D8), doi:10.1029/2001JD001160

Lenaerts, J. T. M., van den Broeke, M. R., Déry, S. J., van Meijgaard, E., van de Berg, W. J., Palm, S. P., \& Sanz Rodrigo, J. (2012) Modeling drifting snow in Antarctica with a regional climate model: 1. Methods and model evaluation. Journal of Geophysical Research: Atmospheres, 117(D5), D05108. doi:10.1029/2011JD016145

Lenaerts, J. T. M., Vizcaino, M., Fyke, J., van Kampenhout, L., \& van den Broeke, M. R. (2016) Present-day and future Antarctic ice sheet climate and surface mass balance in the Community Earth System Model. Climate Dynamics, 47, 1367-1381.

doi:10.1029/2011JD016145

Leung, L. R., \& Ghan, S. J. (1998) Parameterizing subgrid orographic precipitation and surface cover in climate models. Monthly Weather Review, 126, 3271-3291.

Lipscomb, W. H., Fyke, J. G., Vizcaíno, M., Sacks, W. J., Wolfe, J., Vertenstein, M., et al. (2013) Implementation and initial evaluation of the Glimmer Community Ice Sheet Model in the Community Earth System Model. Journal of Climate, 26(19), 7352-7371, doi:10.1175/JCLI-D-12-00557.1.

Lund, M., Stiegler, C., Abermann, J., Citterio, M., Hansen, B. U., \& van As, D. (2017) Spatiotemporal variability in surface energy balance across tundra, snow and ice in Greenland. Ambio, 46 (Suppl. 1), S81-S93, doi: 10.1007/s13280-016-0867-5.

Mattingly, K. S., Mote, T. L., and Fettweis, X. (2018) Atmospheric river impacts on Greenland ice sheet surface mass balance. Journal of Geophysical Research, Atmospheres, 123, 16, doi: 10.1029/2018JD028714.

Marshall, J. \& Plumb, R.A. (2008) Atmosphere, ocean, and climate dynamics: an introductory text. Amsterdam, Netherlands and Burlington, MA: Elsevier Academic Press.

Miller, N. B., Shupe, M. D., Lenaerts, J. T. M., Kay, J. E., de Boer, G., \& Bennartz, R. (2018) Process-based model evaluation using surface energy budget observations in central Greenland. Journal of Geophysical Research: Atmospheres, 123. doi: 10.1029/2017JD027377.

Nick, F. M., Vieli, A., Andersen, M. L., Joughin, I., Payne, A., Edwards, T. L., Pattyn, F., \& van de Wal, R. S. W. (2013) Future sea-level rise from Greenland's main outlet glaciers in a warming climate. Nature, 497(7448), 235-238. doi:10.1038/nature12068

Noël, B., van de Berg, W. J., van Meijgaard, E., Kuipers Munneke, P., van de Wal, R. S. W., $\&$ van den Broeke, M. R. (2015) Evaluation of the updated regional climate model RACMO2.3: summer snowfall impact on the Greenland ice sheet. The Cryosphere, 9(5), 1831-1844. doi:10.5194/tc-9-1831-2015

Nowicki, S., Bindschadler, R. A., Abe-Ouchi, A., Aschwanden, A., Bueler, E., Choi, H., et al. (2013) Insights into spatial sensitivities of ice mass response to environmental change from the SeaRISE ice sheet modeling project I: Antarctica. Journal of Geophysical Research: Earth Surface, 118(2), 1002-1024. doi:10.1002/jgrf.20081

Nowicki, S. M. J., Payne, A., Larour, E., Seroussi, H., Goelzer, H., Lipscomb, W., et al. (2016) Ice sheet model intercomparison project (ISMIP6) contribution to CMIP6. Geoscientific Model Development, 9(12), 4521-4545. doi:10.5194/gmd-9-4521-2016

Rae, J. G. L., Aðalgiersdóttir, G., Edwards, T. L., Fettweis, X., Gregory, J. M., Hewitt, H. T., et al. (2012) Greenland ice sheet surface mass balance: evaluating simulations and making 
projections with regional climate models. The Cryosphere, 6(6), 1275-1294. doi:10.5194/tc6-1275-2012

Reeh, N. (1991) Parameterization of melt rate and surface temperature on the Greenland ice sheet. Polarforschung, 59(3), 113-128.

Rignot, E., Velicogna, I., van den Broeke, M. R., Monaghan, A., \& Lenaerts, J. T. M. (2011) Acceleration of the contribution of the Greenland and Antarctic ice sheets to sea level rise. Geophysical Research Letters, 38(5), L05503. doi:10.1029/2011GL046583

Rothman, L. S., Gordon, I. E., Babikov, Y., Barbe, A., Benner, D. C., Bernath, P. F., et al. (2013) The HITRAN2012 molecular spectroscopic database. Journal of Quantitative Spectroscopy and Radiative Transfer, 130, 4-50, doi: 10.1016/j.jsqrt.2013.07.002.

Schlegel, N., Larour, E., Seroussi, H., \& Box, J. E. (2015) Ice discharge uncertainties in Northeast Greenland from boundary conditions and climate forcing of an ice flow model. Journal of Geophysical Research: Earth Surface, 120(1), 29-54. doi:10.1002/2014JF003359

Schmidt, G. A., Ruedy, R., Hansen, J. E., Aleinov, I., Bell, N., Bauer, M., et al. (2006) Present-day atmospheric simulations using GISS ModelE: Coparisons to in situ, satellite, and reanalysis data. Journal of Climate, 19(2), 153-192. doi:10.1175/JCLI3612.1

Schmidt, G., Kelley, M., Nazarenko, L., Ruedy, R., Russell, G. L., Aleinov, I., et al. (2014) Configuration and assessment of the GISS ModelE2 contributions to the CMIP5 archive. Journal of Advances in Modeling Earth Systems, 6(1), 141-184. doi:10.1002/2013MS000265

Shepherd, A., Ivins, E. R., A, G., Barletta, V. R., Bentley, M. G., Bettadpur, S., et al. (2012) A reconciled estimate of ice-sheet mass balance. Science, 338(6111), 1183-1189.

doi:10.1126/science. 1228102

Smeets, P. C. J. P., Kuipers Munneke, P., van As, D., van den Broeke, M. R., Boot, W., Oerlemans, H., et al. (2018) The K-transect in west Greenland: Automatic weather station data (1993-2016). Arctic, Antarctic and Alpine Research, 50, 1, doi: 10.1080/15230430.2017.1420954.

Steffen, K. \& Box, J. E. (2001) Surface climatology of the Greenland ice sheet: Greenland Climate Network 1995-1999. Journal of Geophysical Research, 106(D12), 33951-33964. doi:10.1029/2001JD900161

Steger, C. R., Reijmer, C. H., van den Broeke, M. R., Wever, N., Forster, R. R., Koenig, L. S., et al. (2017) Firn meltwater retention on the Greenland ice sheet: a model comparison. Frontiers in Earth Science, 5. doi:10.3389/feart.2017.00003

Tedesco, M., Serreze, M., \& Fettweis, X. (2008) Diagnosing the extreme surface melt event over southwestern Greenland in 2007. The Cryosphere, 2, 159-166. doi:10.5194/tc-2-1592008

Tedesco, M. \& Alexander, P. (2013) MODIS (MOD10A1) albedo data on the MAR RCM grid (2000-2013). NSF Arctic Data Archive. doi:10.18739/A2SK7T

Tedesco, M., Doherty, S., Fettweis, X., Alexander, P., Jeyaratnam, J., \& Stroeve, J. (2016) The darkening of the Greenland ice sheet: trends, drivers, and projections (1981-2100). The Cryosphere, 10, 477-496. doi:10.5194/tc-10-477-2016

van Angelen, J. H., Lenaerts, J. T. M., Lhermitte, S., Fettweis, X., Kuipers Munneke, P., van den Broeke, et al. (2012) Sensitivity of the Greenland ice sheet surface mass balance to surface albedo parameterization: a study with a regional climate model. The Cryosphere, 6(5), 1175-1186. doi:10.5194/tc-6-1175-2012 
van Angelen, J. H., van den Broeke, M. R., Wouters, B., \& Lenaerts, J. T. M. (2014) Contemporary (1960-2012) evolution of the climate and surface mass balance of the Greenland ice sheet. Surveys in Geophysics, 35(5), 1155-1174. doi:10.1007/s10712-0139261-z

van den Broeke, M., Bamber, J., Ettema, J., Rignot, E., Schrama, E. \& van de Berg, W. J. (2009) Partitioning recent Greenland mass loss. Science, 326(5955), 984-986.

doi:10.1126/science.1178176

van den Broeke, M. R., Smeets, C. J. P. P., \& van den Wal, R. S. W. (2011) The seasonal cycle and interannual variability of the surface energy balance and melt in the ablation zone of the west Greenland ice sheet. The Cryosphere, 5, 377-390. doi: 105194/tc-5-377-2011.

van den Broeke, M. R., Enderlin, E. M., Howat, I. M., Kuipers Munneke, P., Noël, B. P. Y., van de Berg, W. J., et al. (2016) On the recent contribution of the Greenland ice sheet to sea level change. The Cryosphere, 10(5), 1933-1946. doi:5194/tc-10-1933-2016

Velicogna, I., Sutterly, T. C., \& van den Broeke, M. R. (2017) Regional acceleration in ice mass loss from Greenland and Antarctica using GRACE time-variable gravity data.

Geophysical Research Letters, 41, 8130-8137, doi:10.1002/2014GL061052

Vernon, C. L., Bamber, J. L., Box, J. E., van den Broeke, M. R., Fettweis, X., Hanna, E., \& Huybrechts, P. (2013) Surface mass balance model intercomparison for the Greenland ice sheet. The Cryosphere, 7(2), 599-614. doi:10.5194/tc-7-599-2013

Vizcaíno, M., Lipscomb, W. H., Sacks, W. J., van Angelen, J. H., Wouters, B., \& van den Broeke, M. R. (2013) Greenland surface mass balance as simulated by the Community Earth System Model. Part 1: Model Evaluation and 1850-2005 results. Journal of Climate, 26(20), 7793-7812. doi:10.1175/JCLI-D-12-00615.1

Yao, M.-S., and Cheng, Y. (2012) Cloud simulations in response to turbulence parameterizations in the GISS Model E GCM. Journal of Climate, 25, 4963-4974, doi: 10.1175/JCLI-D-11-00399.1.

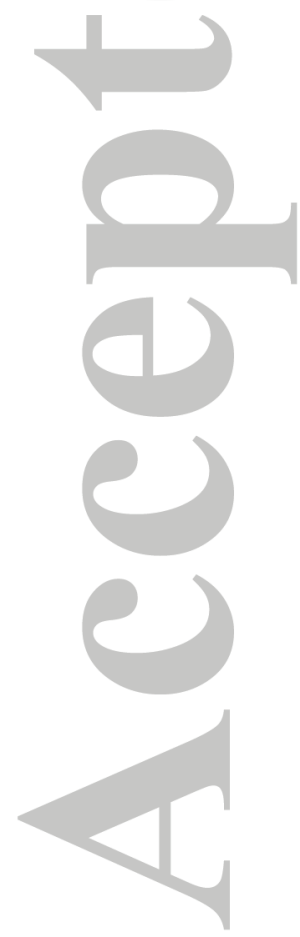




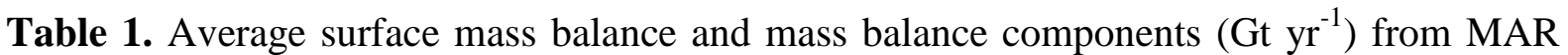
(1996-2005) and ModelE2 (1996-2005 forcing) for different configurations of ModelE2. The uncertainty ranges indicate the standard deviation of annual SMB. *Note that refreezing is not taken into account in ModelE2.

\begin{tabular}{|c|c|c|c|c|c|c|c|c|}
\hline Simulation & SMB & Snowfall & Rainfall & Melt & $\begin{array}{l}\text { Meltwater } \\
\text { Refreezing }\end{array}$ & Runoff & $\begin{array}{c}\text { Sublimation } \\
+ \text { Evaporation }\end{array}$ & Description \\
\hline $\begin{array}{l}\text { MAR (ERA- } \\
\text { Interim forcing) }\end{array}$ & $420 \pm 99$ & $730 \pm 45$ & $40 \pm 8$ & $579 \pm 96$ & $267 \pm 31$ & $340 \pm 73$ & $11 \pm 4$ & $\begin{array}{l}\text { RCM } 25 \mathrm{~km} \\
\text { resolution }\end{array}$ \\
\hline E2-control & $471 \pm 32$ & $832 \pm 46$ & $66 \pm 8$ & $188 \pm 13$ & $*$ & $254 \pm 17$ & $173 \pm 13$ & $\mathrm{GCM} 2^{\circ} \times 2.5^{\circ}$ \\
\hline E2-2ECs & $534 \pm 91$ & $812 \pm 81$ & $74 \pm 16$ & $92 \pm 27$ & $*$ & $166 \pm 38$ & $186 \pm 7$ & $\begin{array}{c}\text { E2-control with } \\
2 \text { elev. classes (ECs) }\end{array}$ \\
\hline E2-20ECs & $509 \pm 66$ & $816 \pm 67$ & $62 \pm 11$ & $130 \pm 24$ & $*$ & $192 \pm 33$ & $176 \pm 10$ & $\begin{array}{l}\text { E2-control, with } \\
20 \mathrm{ECs}\end{array}$ \\
\hline E2-20ECs-Sat- $\alpha$ & $376 \pm 64$ & $841 \pm 56$ & $82 \pm 14$ & $278 \pm 45$ & $*$ & $360 \pm 54$ & $187 \pm 4$ & $\begin{array}{c}20 \text { ECs, MODIS } \\
\text { albedo }\end{array}$ \\
\hline E2-20ECs- $\alpha$-f(age) & $243 \pm 117$ & $838 \pm 85$ & $80 \pm 14$ & $370 \pm 57$ & $*$ & $449 \pm 56$ & $226 \pm 8$ & $\begin{array}{l}20 \text { ECs, snow age } \\
\text { albedo scheme }\end{array}$ \\
\hline E2-20ECs-Z $z_{0}$-adj & $652 \pm 55$ & $885 \pm 49$ & $76 \pm 13$ & $139 \pm 27$ & $*$ & $215 \pm 38$ & $94 \pm 6$ & $\begin{array}{c}20 \text { ECs with adjusted } \\
\text { roughness length }\end{array}$ \\
\hline
\end{tabular}



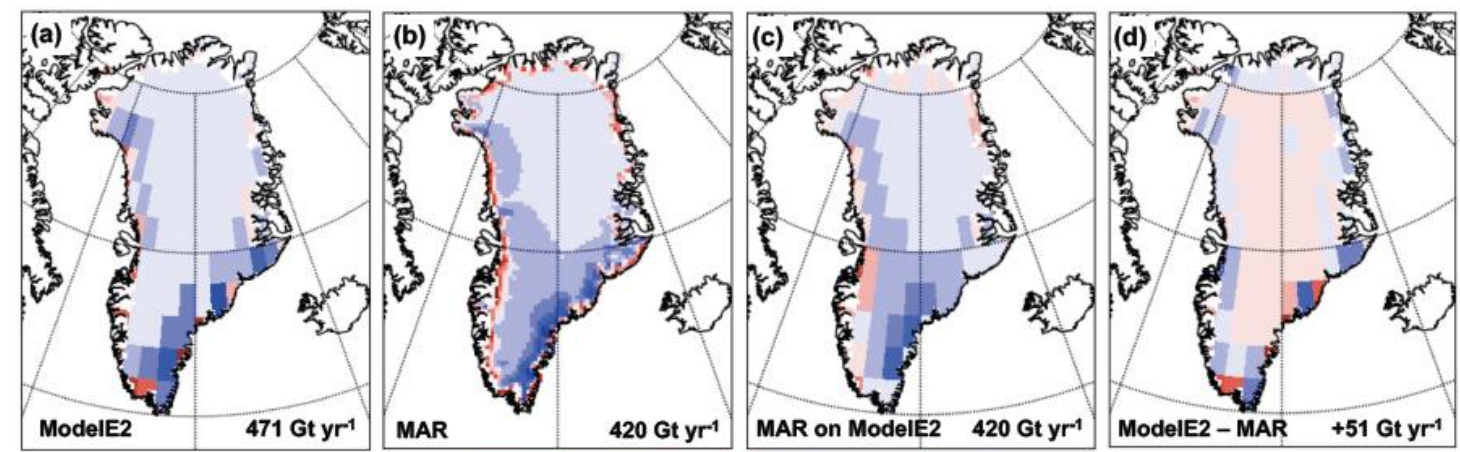

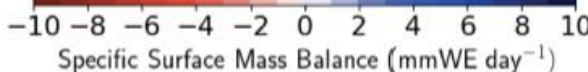

Figure 1. GrIS specific surface mass balance (SMB in mmWE day ${ }^{-1}$ ) from (a) The last 10 years of the 11-year ModelE control simulation, (b) MAR for the period 1996-2005 and (c) MAR averaged on the ModelE grid. The difference between MAR and ModelE2 on the ModelE2 grid is shown in (d). Numbers at the lower right of each panel give the average

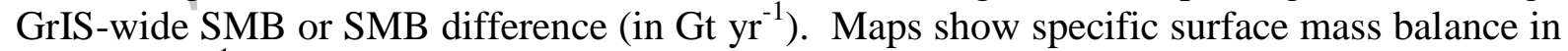
mmWE day ${ }^{1}$ rather than Gt as these units are more suitable for the variable-area ModelE2 grid. Areas outside the GrIS as defined by MAR have been masked out. 

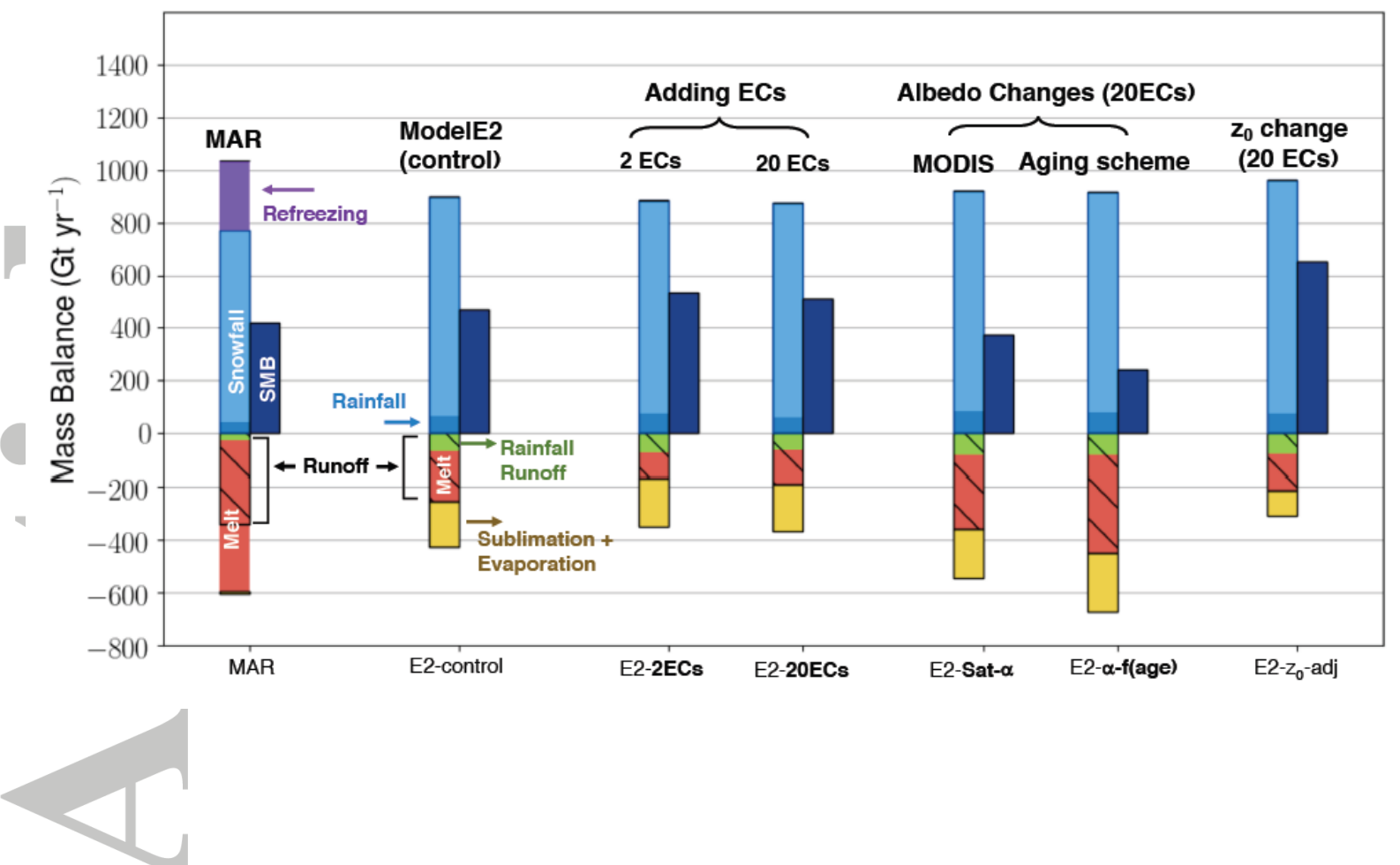

Figure 2. Average GrIS-wide surface mass balance and components from MAR (1996-2005) and ModelE2, with different configurations of ModelE2 (10-yr average with 1996-2005 forcing), including simulations with 2 and 20 elevation classes (E2-2ECs and E2-20ECs), replacing fixed ice sheet albedo with MODIS-derived albedo (2000-2012) for the 20EC simulations (E2-Sat- $\alpha$ ) and age-dependent albedo (E2- $\alpha-f($ age $)$ ), and a simulation in which the effect of topography on ModelE2 roughness length has been removed (E2- $\mathrm{Z}_{0}$-adj). 


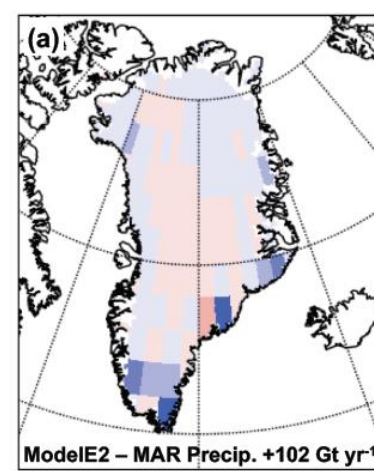

ModelE2 - MAR Precip. +102 Gt yr

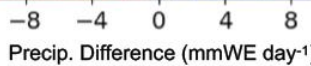

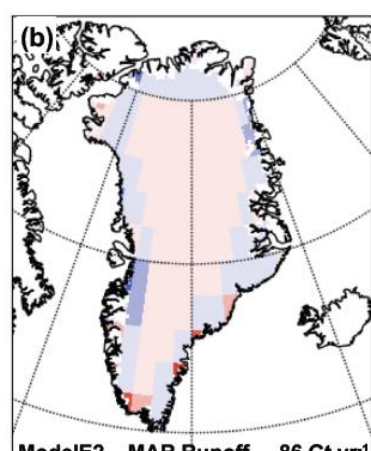

ModelE2 - MAR Runoff $\quad-86 \mathrm{Gt}$

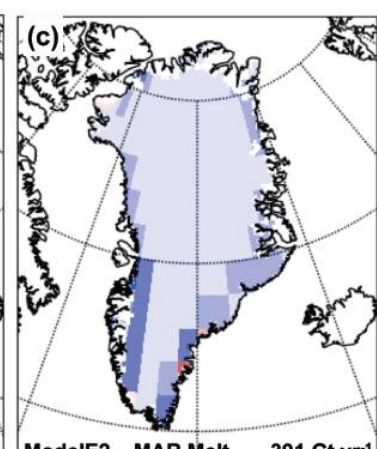

ModelE2 - MAR Melt $\quad-391{\mathrm{Gt} \mathrm{yr}^{-1}}^{-1}$

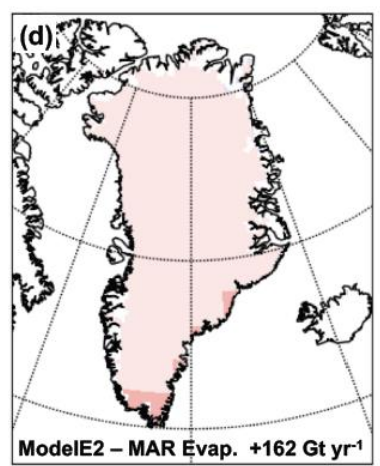

$\begin{array}{lllllllllll}-10 & -8 & -6 & -4 & -2 & 0 & 2 & 4 & 6 & 8 & 10\end{array}$

Runoff, Melt or Evap. Difference (mmWE day-1)

Figure 3. Differences between MAR (1996-2005) and the ModelE2 control simulation (10-yr average with 1996-2005 forcing) for SMB components, including (a) precipitation, (b) runoff, (c) melt, and (d) evaporation + sublimation.

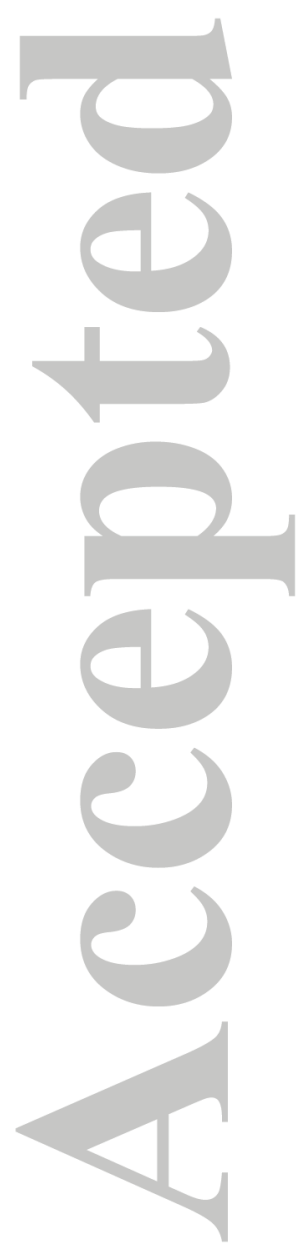



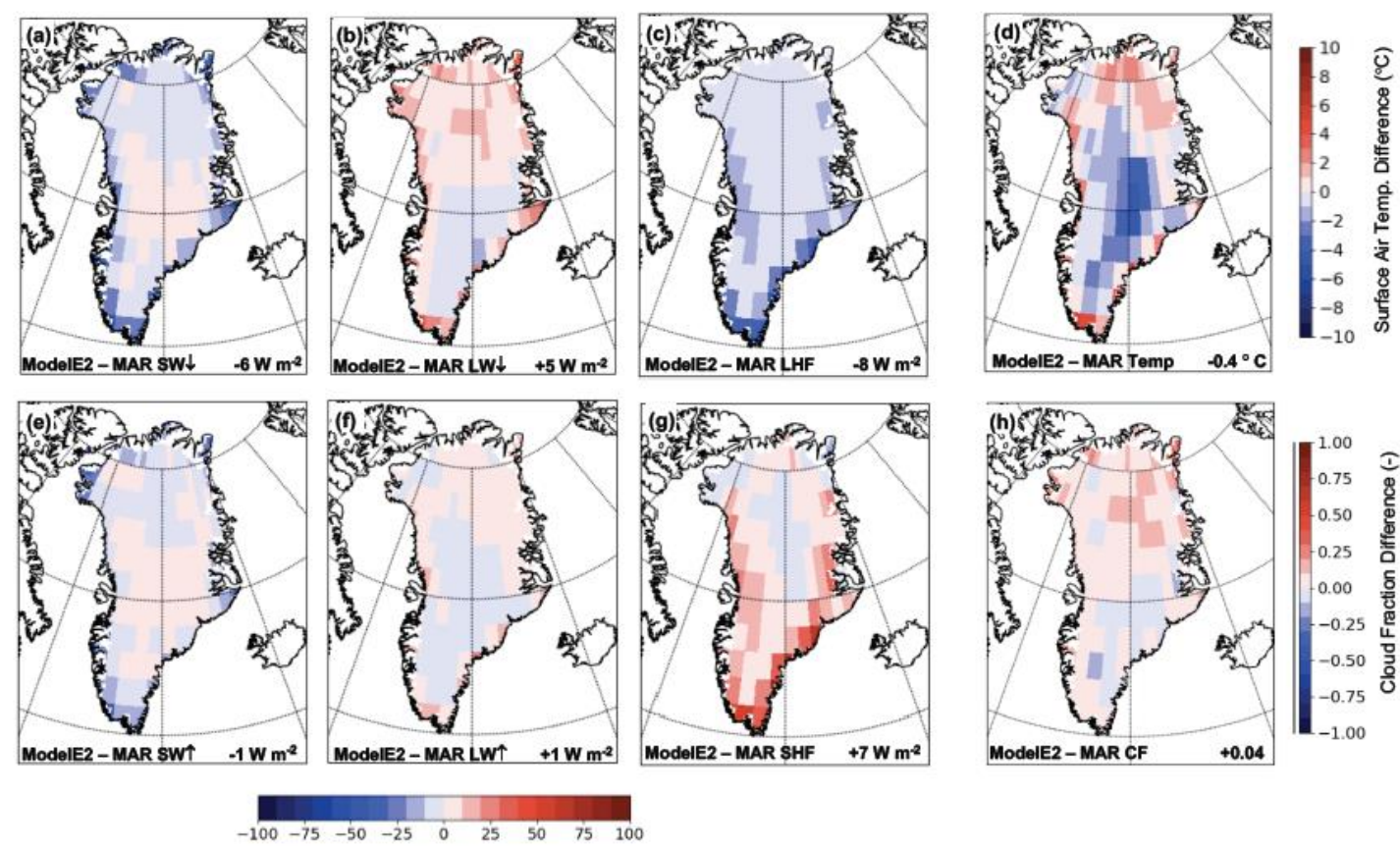

Energy Flux Difference $\left(\mathrm{W} \mathrm{m}^{-2}\right)$

Modele2 - MAR CF $\quad+\mathbf{0 . 0 4}$

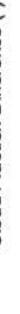



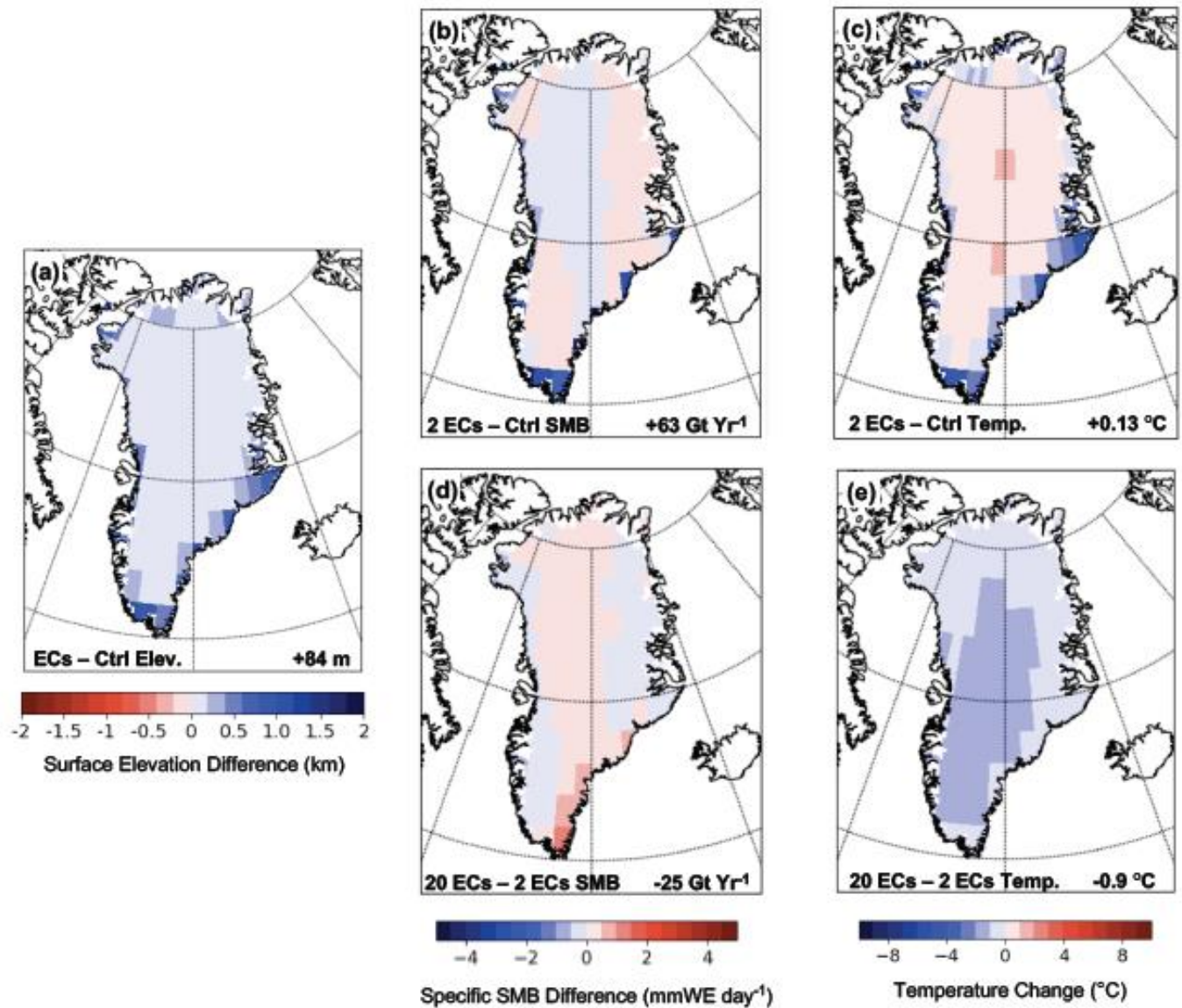

Figure 5. (a) Difference in surface elevation between the elevation class (EC) simulations and the ModelE2 control simulation. (b) Change in SMB associated with adding 2 elevation classes (ECs) to the ModelE2 control simulation (E2-EC2-ALfix - E2-EC1-ALfix). (c) Same as (b) for surface air temperature. (d) Same as (b) for the simulation with 20 ECs relative to the 2 EC simulation (E2-EC20-ALfix - E2-EC2-ALfix). (e) Same as (d) for surface air temperature. 

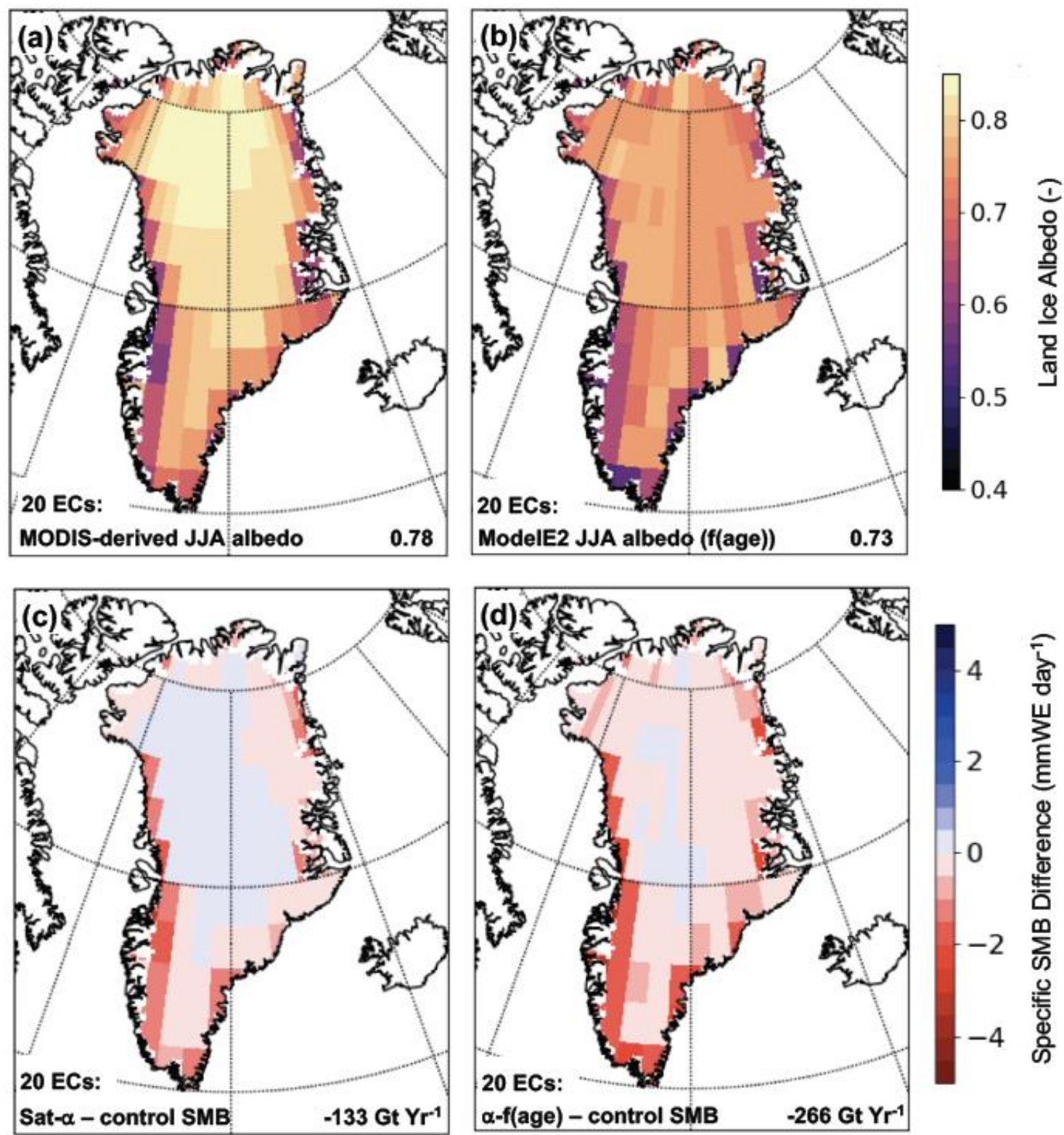

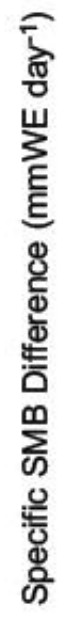

Figure 6. (a) Ten-year average June-July-August (JJA) land-ice albedo from the E2-20ECsSat- $\alpha$ ModelE2 simulation, which uses MODIS MOD10A1 average monthly albedo (20002012) during June, July, and August, with 20 elevation classes. (b) Change in average annual SMB for the E2-20ECs-Sat- $\alpha$ simulation relative to E2-20ECs. (c) Same as (a) for the E2$20 \mathrm{ECs}-\alpha-\mathrm{f}$ (age) simulation. (d) Same as (b) for the E2-20ECs- $\alpha-f($ age) simulation.

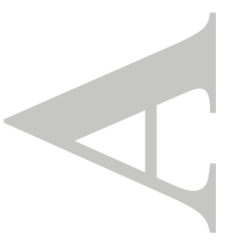




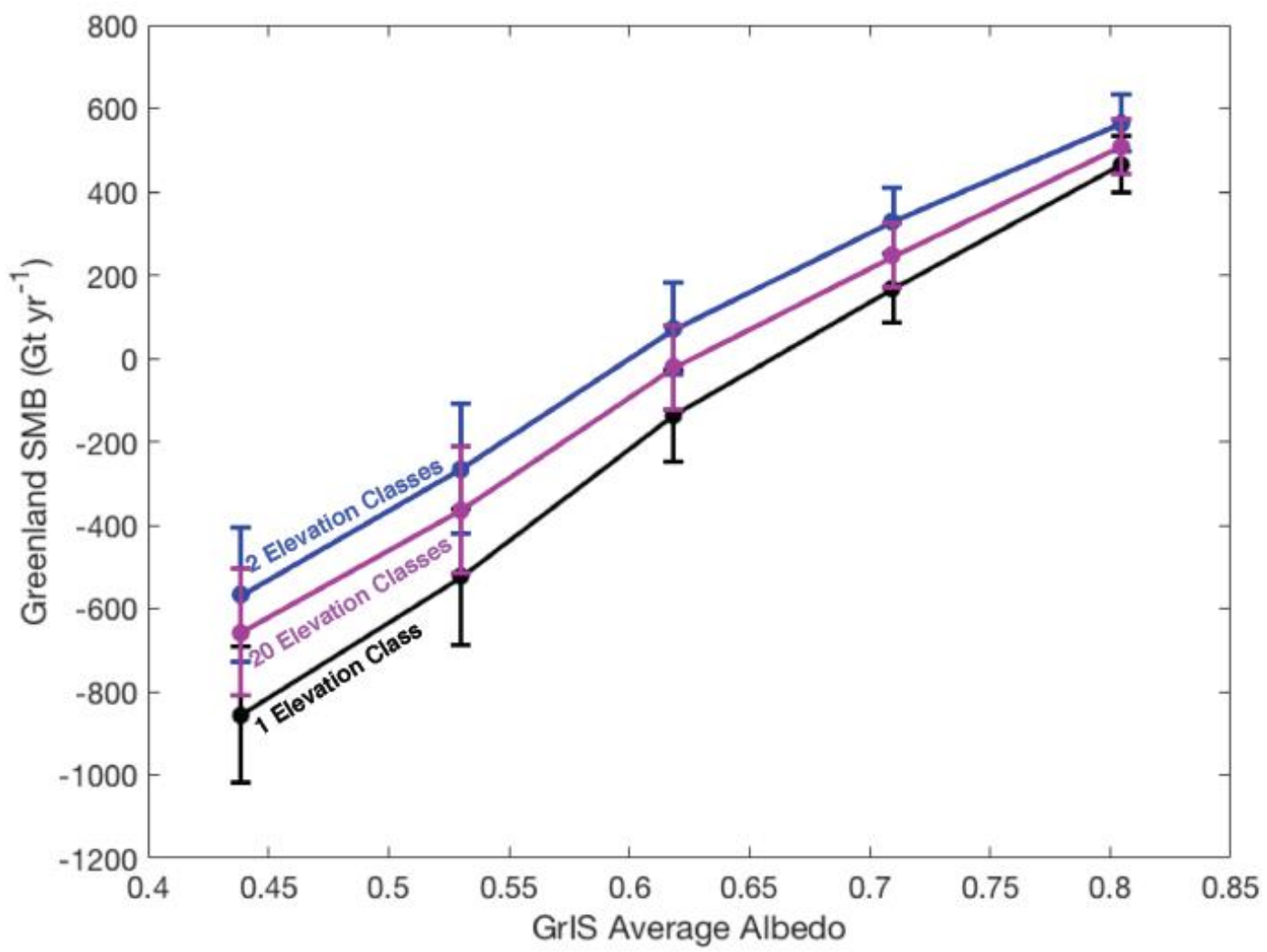

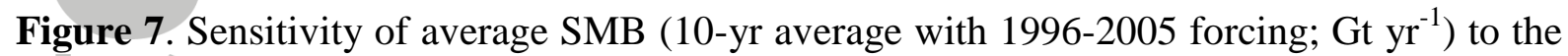
specified value for fixed ice sheet albedo in ModelE2 simulations. (Note that the atmosphere is fully interactive only for the simulation with 20 elevation classes.) 